\title{
Abordagem clínica não-cirúrgica no tratamento da má oclusão de Classe III
}

\author{
Eustáquio A. Araújo*, Cristiana V. de Araújo**
}

\section{Resumo}

A abordagem clínica não-cirúrgica da Classe III coloca-se entre os grandes desafios da Ortodontia e vem, desde sempre, gerando controvérsia entre clínicos e pesquisadores. Alguns defendem a tese de que o crescimento e o desenvolvimento do complexo craniofacial são determinados geneticamente e, portanto, inalteráveis. Para esses, a correção da grande maioria de casos de Classe III passará por intervenções orto-cirúrgicas, devendo a terapia ser realizada assim que cessar o período mais ativo do crescimento. Por outro lado, há aqueles que, mesmo concordando com o peso da hereditariedade na etiologia da Classe III, acreditam ser possível modificar o padrão e a direção do crescimento e, através de uma abordagem não-cirúrgica, minimizar a má oclusão ou até mesmo tratá-la com sucesso. Em face da controvérsia, quais seriam as possibilidades ortodônticas? Inúmeros são os relatos de que uma intervenção adequada, em momento adequado, acompanhada de um estudo do padrão familiar, pode, muitas vezes, minimizar o desenvolvimento de uma Classe III. Procedimentos selecionados com critério podem reduzir a indicação de intervenções cirúrgicas e proporcionar resultados positivos e duradouros. Há evidências clínicas e científicas de que algumas decisões terapêuticas podem mudar o curso de muitos prognósticos sombrios.

Palavras-chave: Tratamento da Classe III. Má oclusão. Camuflagem da Classe III.

\section{INTRODUÇÃO}

A má oclusão de Classe III é um tipo de desvio dentoesqueletal cuja incidência varia entre 3\% e $13 \%$ da população, conforme registros diver$\operatorname{sos}^{19,29,33}$. Esses números se modificam com base na procedência étnica dos observados. Uma prevalência aproximada de $6 \%$ parece ser mais consensual entre clínicos na América do Norte e no Brasil.
No aspecto psicológico, é importante ressaltar que, dentre os portadores de má oclusão, os de Classe III costumam apresentar os índices mais baixos de auto-estima ${ }^{15}$ (Gráf. 1).

A abordagem da Classe III requer cuidados especiais no diagnóstico e nas decisões quanto à época de tratamento e tipos de intervenção. Não há, no entanto, unanimidade entre os autores quanto a essas questões. De fato, a literatura ortodôntica

\footnotetext{
* Especialista e mestre em Ortodontia pela University of Pittsburgh. Professor e Asst. Program Director Center for Advanced Dental Education - Saint Louis University.

** Cirurgiã-dentista pela PUC-Minas. Mestranda do programa de Ortodontia do Center for Advanced Dental Education - Saint Louis University, St Louis, MO.
} 
é repleta de trabalhos com relatos de condutas diversas no tocante ao problema. Não são poucos os que advogam que a cirurgia pós-crescimento é o procedimento indicado para se tratar esse desvio. Outros propõem que o problema seja tratado durante a fase de crescimento.

O não-tratamento pode agravar a severidade do problema. Nas figuras 1 e 2, por exemplo, observase uma paciente cuja má oclusão, de certa forma, não era objeto de grandes preocupações, por volta

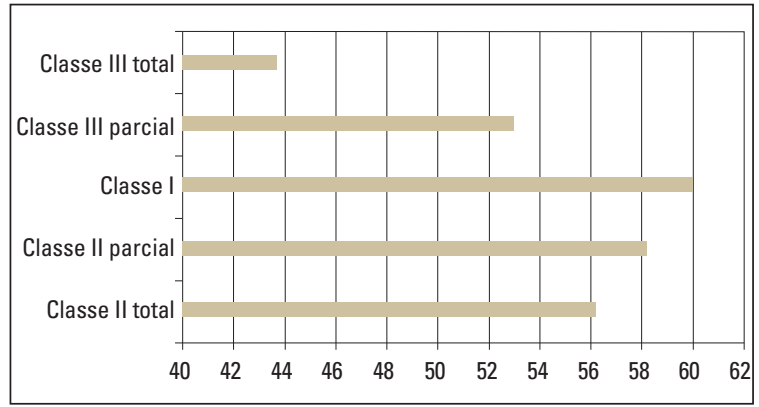

GRÁFICO 1 - Índices de avaliação da auto estima em relação aos diversos tipos de má oclusão (FONTE: Adaptado de GRABER, LUCKER ${ }^{15}$ ).
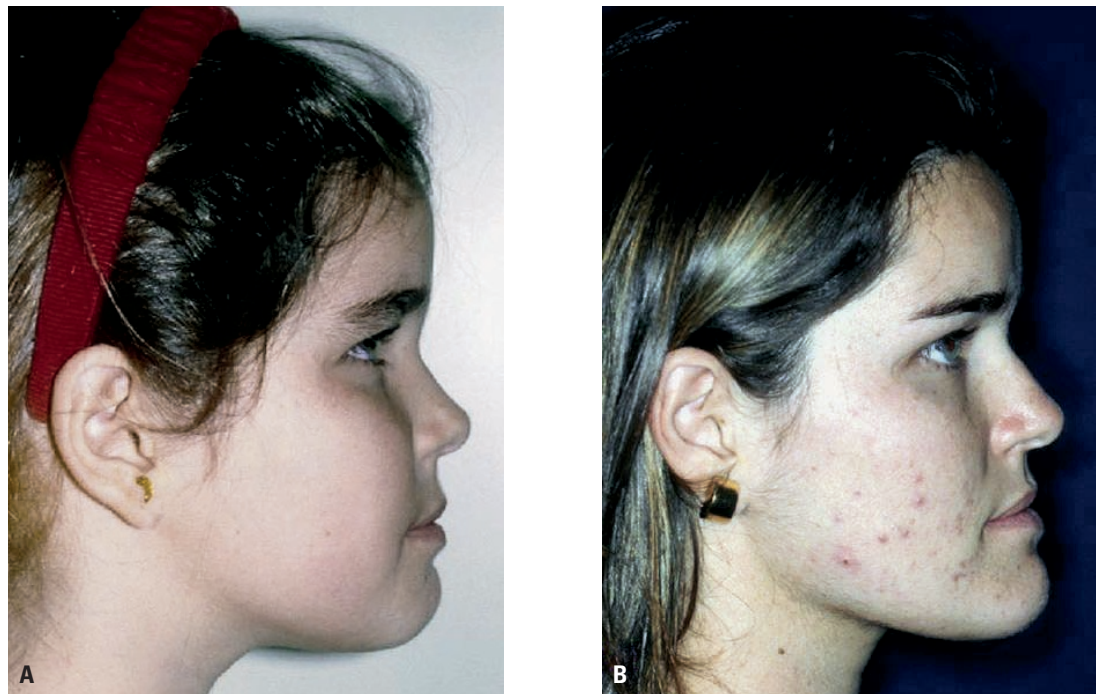

FIGURA 1 - Fotografias extrabucais de paciente sem tratamento, em idade: A) pré-puberal; B) pós-puberal.
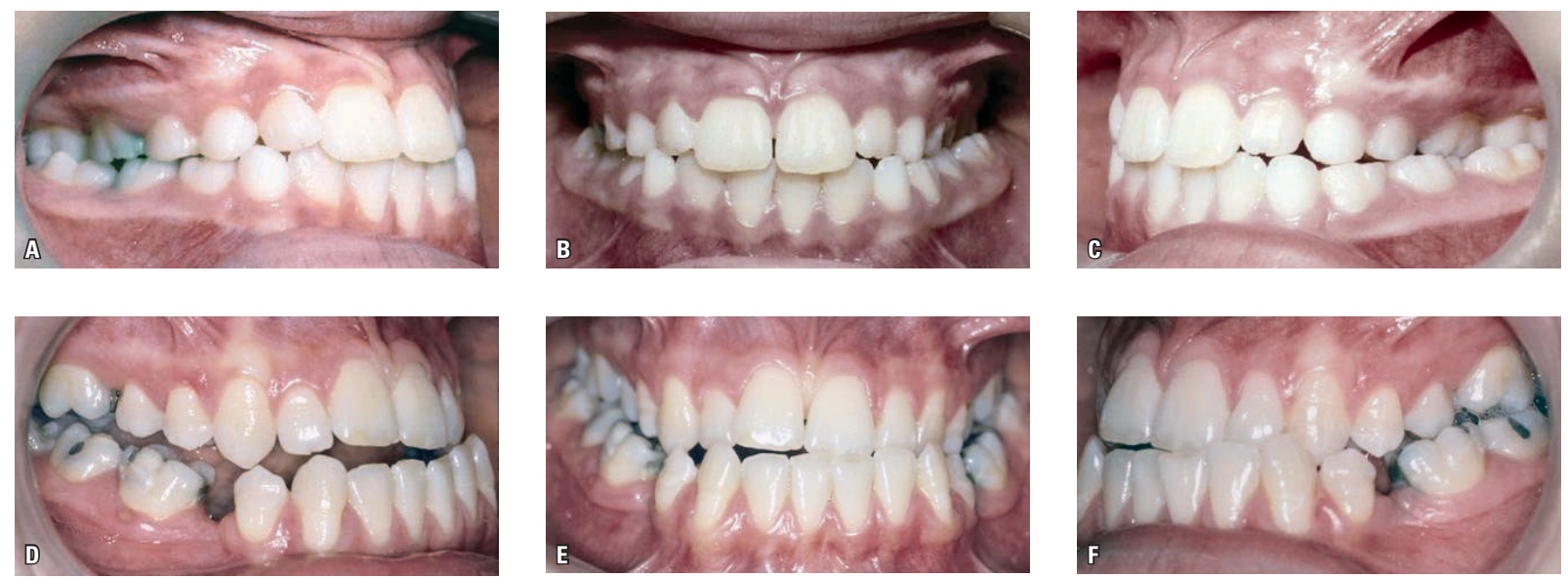

FIGURA 2 - Fotografias intrabucais de paciente sem tratamento, em idade: A, B, C) pré-puberal, D, E, F) pós-puberal. 
dos 10 anos de idade. Com o passar do tempo, no entanto, atingiu um grau de severidade tal que a transferiu para o grupo de casos a serem tratados por procedimento orto-cirúrgico mais complexo.

Vale questionar, embora não se tenha condição de responder, se uma intervenção através de procedimento ortodôntico e ortopédico poderia alterar o curso dessa má oclusão. São claras as mudanças faciais e dentárias, sem tratamento ortodôntico, na fase pré-puberal e no período pós-puberal.

De acordo com Bacetti, Franchi e McNamara $\mathrm{Jr}^{8}{ }^{8}$, as más oclusões de Classe III tendem a tornarse mais severas com o passar do tempo, uma vez que o crescimento da mandíbula mantém-se ativo por um período mais longo que o da maxila. Por isso, acreditam que uma intervenção ortopédica em pacientes em crescimento é bem-vinda e deve ser executada.

\section{Por que antecipar uma intervenção se um cres- cimento desfavorável ainda poderá ocorrer?}

O tratamento não-cirúrgico de uma má oclusão de Classe III é, essencialmente, uma camuflagem que possibilita uma melhor harmonia da face. Consiste na adoção de procedimentos que, desde a dentadura mista, tracionem a maxila anteriormente e redirecionem a mandíbula em sentido horário, para baixo e para trás. A abordagem é contra-indicada para pacientes com características de face longa (mordida aberta), uma vez que a rotação mandibular agravaria o problema, aumentando a probabilidade de correção cirúrgica.

Há vantagens e desvantagens em se utilizar essa conduta. Dentre os aspectos favoráveis, destaca-se o resgate da auto-estima e (re)adaptação social do indivíduo, visto tratar-se de um desvio que afeta muito a estética. Junte-se a esse fator outros igualmente importantes: a possibilidade de se minimizarem futuras intervenções cirúrgicas, se necessárias, e o restabelecimento da função.

Apesar das perspectivas favoráveis, tentativas de se reverter os indicadores de uma Classe III rumo ao ideal costumam causar grande frustração, pois uma perfeita relação esquelética e uma face harmoniosa são metas dificilmente alcançadas sem intervenção cirúrgica conduzida com extrema eficiência.

O caso apresentado nas figuras 3 a 9 e tabela 1 é exemplo de uma terapia bem sucedida.

A paciente, conforme relato próprio e da família, buscava uma alternativa não-cirúrgica para seu problema. Seu histórico médico e dentário não apresentava grandes preocupações. $\mathrm{O}$ caso, no entanto, podia ser classificado como de alta complexidade.

O exame facial revelou um perfil reto, sendo a face ântero-inferior ligeiramente mais longa que o padrão, a região malar plana e o ângulo nasolabial normal. O exame frontal mostrava uma certa harmonia, com boa proporcionalidade entre as estruturas.

O exame cefalométrico indicava, claramente, a presença de uma Classe III esquelética, devido à retrusão maxilar e protrusão mandibular.

Ao exame dentário, foi detectado um apinhamento superior mínimo e um inferior moderado. As medidas dentárias apresentavam discrepância de Bolton moderada desfavorável para o arco maxilar. Os molares e caninos se relacionavam em Classe III. A sobremordida era mínima e a sobres-

Tabela 1 - Medidas cefalométricas pré-tratamento. Os números em parênteses representam as normas para cada medida.

SNA: 79 (82)
SNB: 82 (80)
ANB: -3 (2)
Wits: -7 (-1)
FMA: 26 (25)
U1-SN: 104 (104)
IMPA: 89 (92)
PNS-A: 45 (47)
Ar-Gn: 115 (102)
NSGn: 64 (67)
U1-L1: 135 (130)



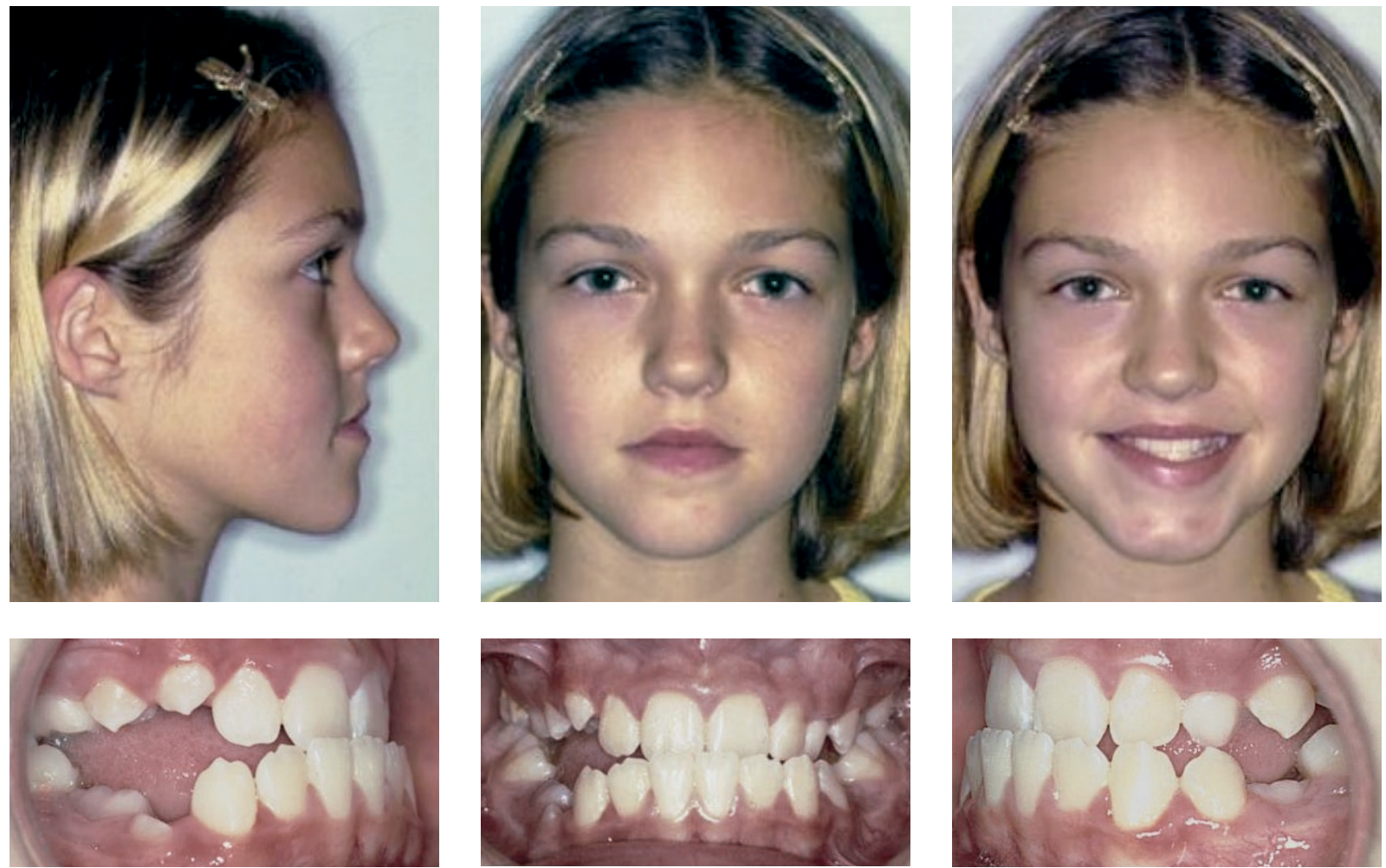

FIGURA 3 - Fotografias extrabucais e intrabucais pré-tratamento.
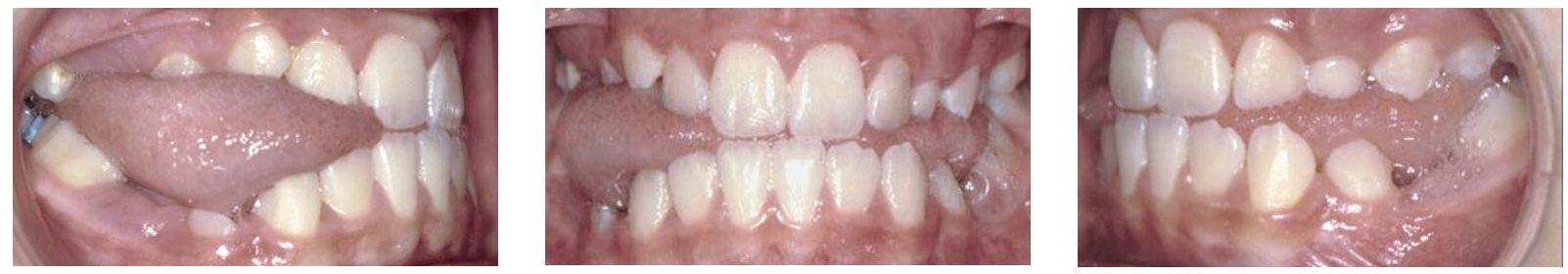

FIGURA 4 - Fotografias intrabucais pré-tratamento, demonstrando severidade da interposição lingual posterior.
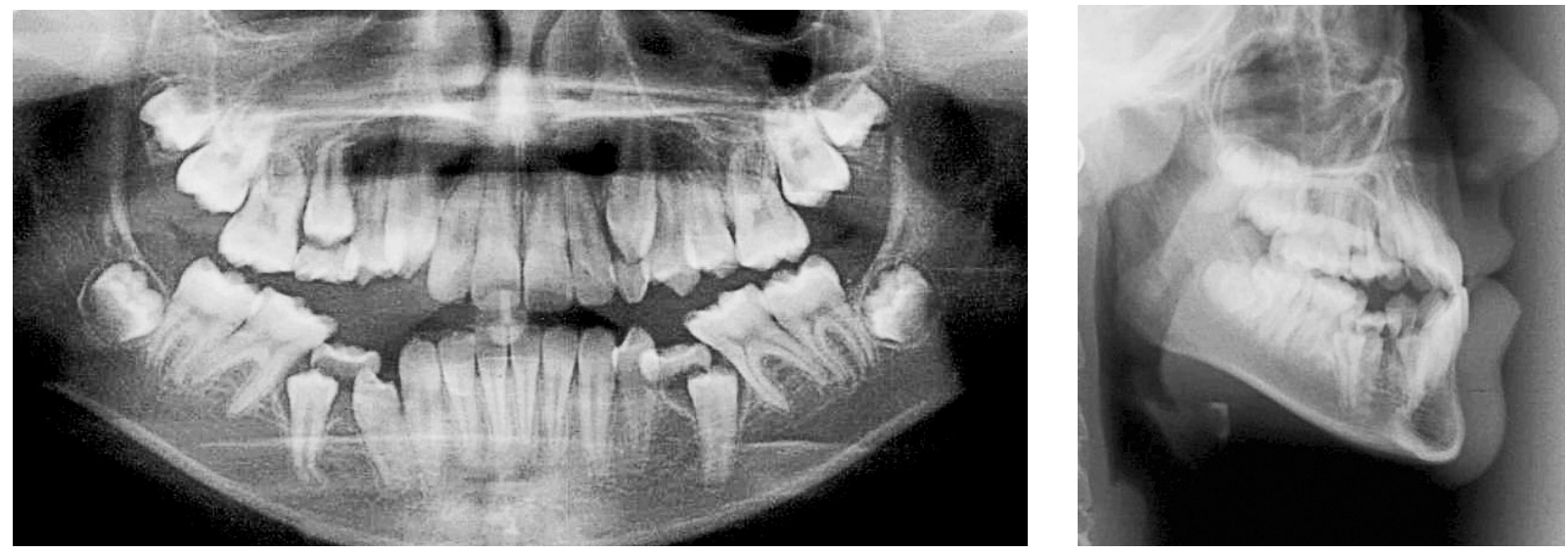

FIGURA 5 - Radiografia panorâmica pré-tratamento.

FIGURA 6 - Radiografia cefalométrica pré-tratamento. 

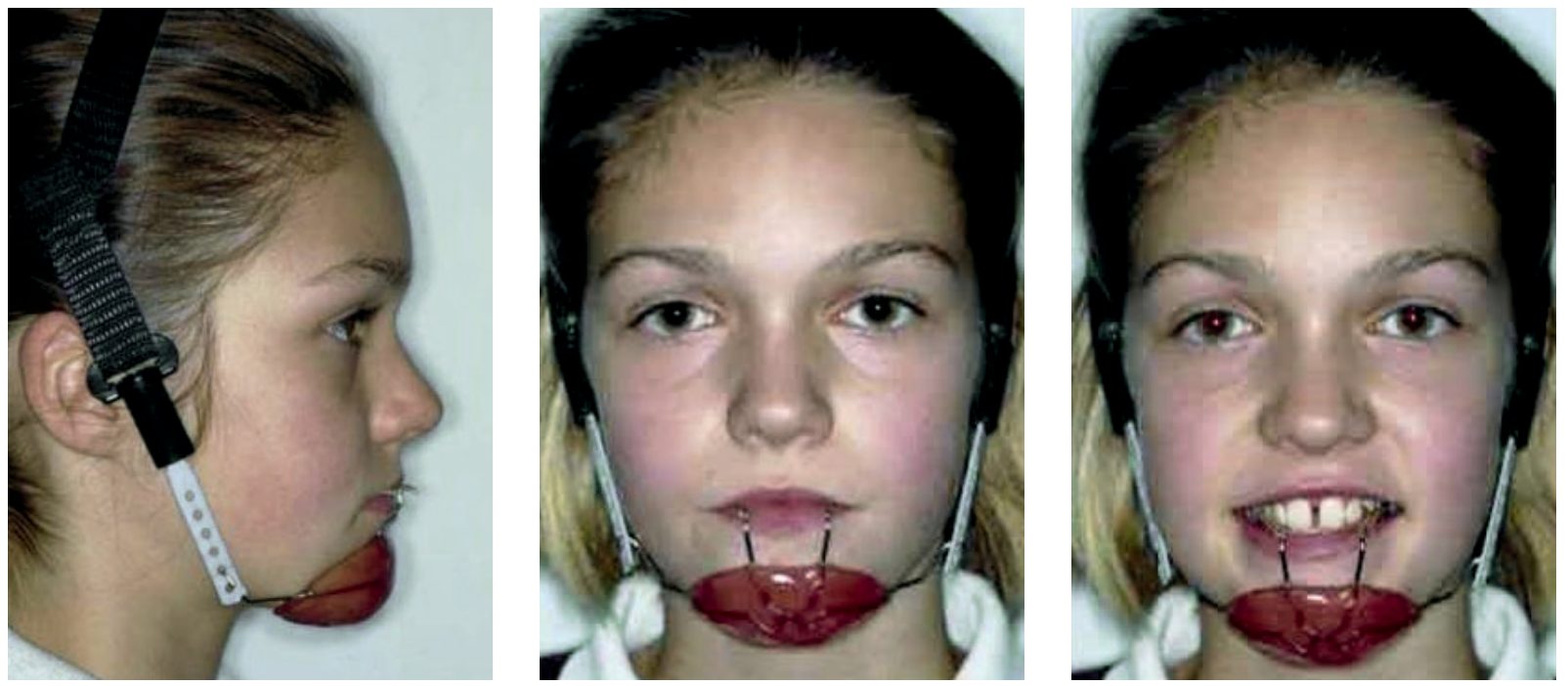

FIGURA 7 - Mentoneira de Hickham para protração maxilar
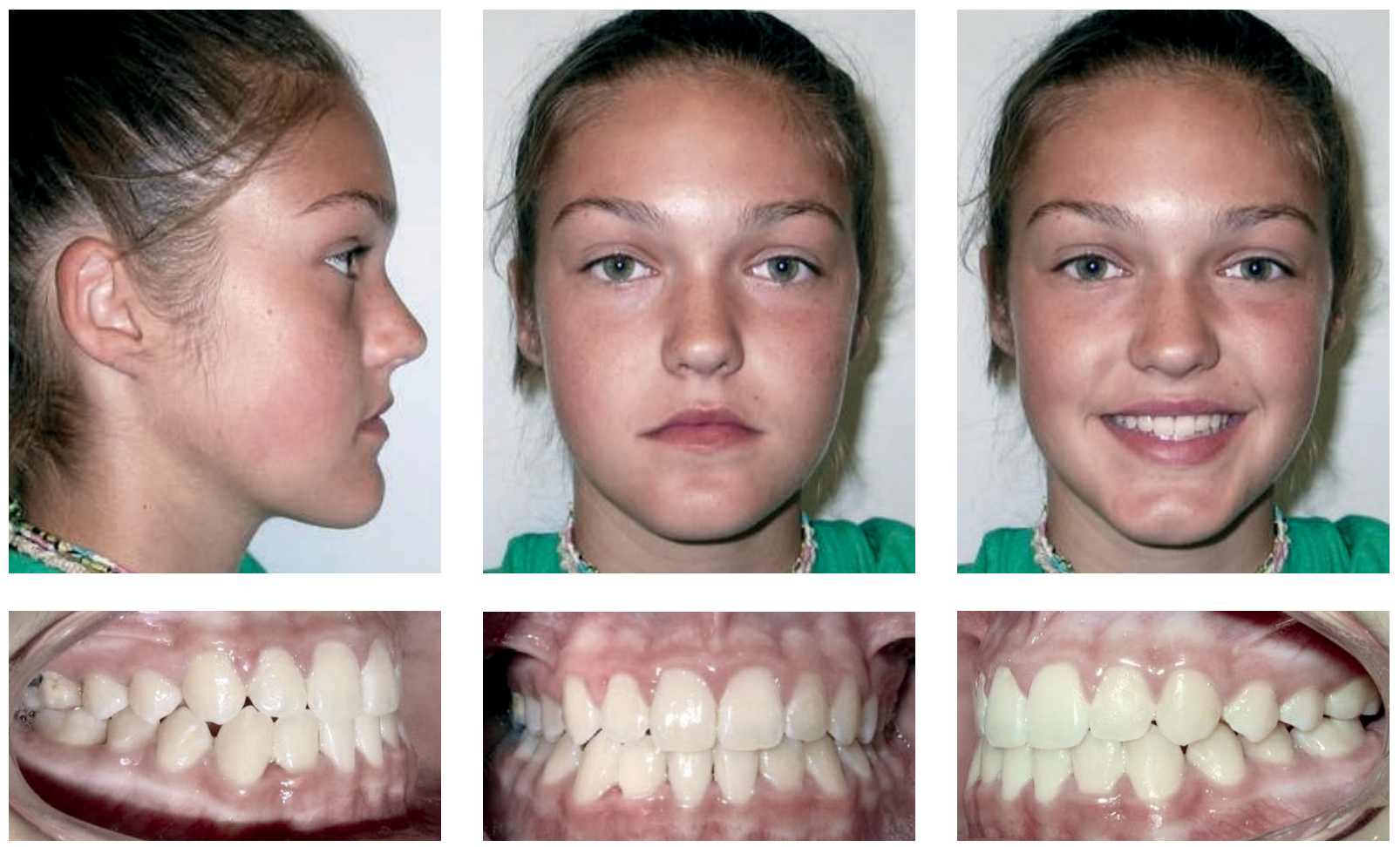

FIGURA 8 - Fotografias extrabucais e intrabucais pós-tratamento, demonstrando harmonia dentária e facial.

saliência negativa. Havia também um desvio da linha média superior de $2 \mathrm{~mm}$ para a esquerda. Um fato complicador era a mordida aberta posterior com projeção lateral da língua na deglutição.
O tratamento incluiu uma expansão rápida da maxila e, simultaneamente, uma protração maxilar por meio da mentoneira de Hickham ${ }^{18}$. Após essa primeira fase, foi realizado tratamento corretivo 

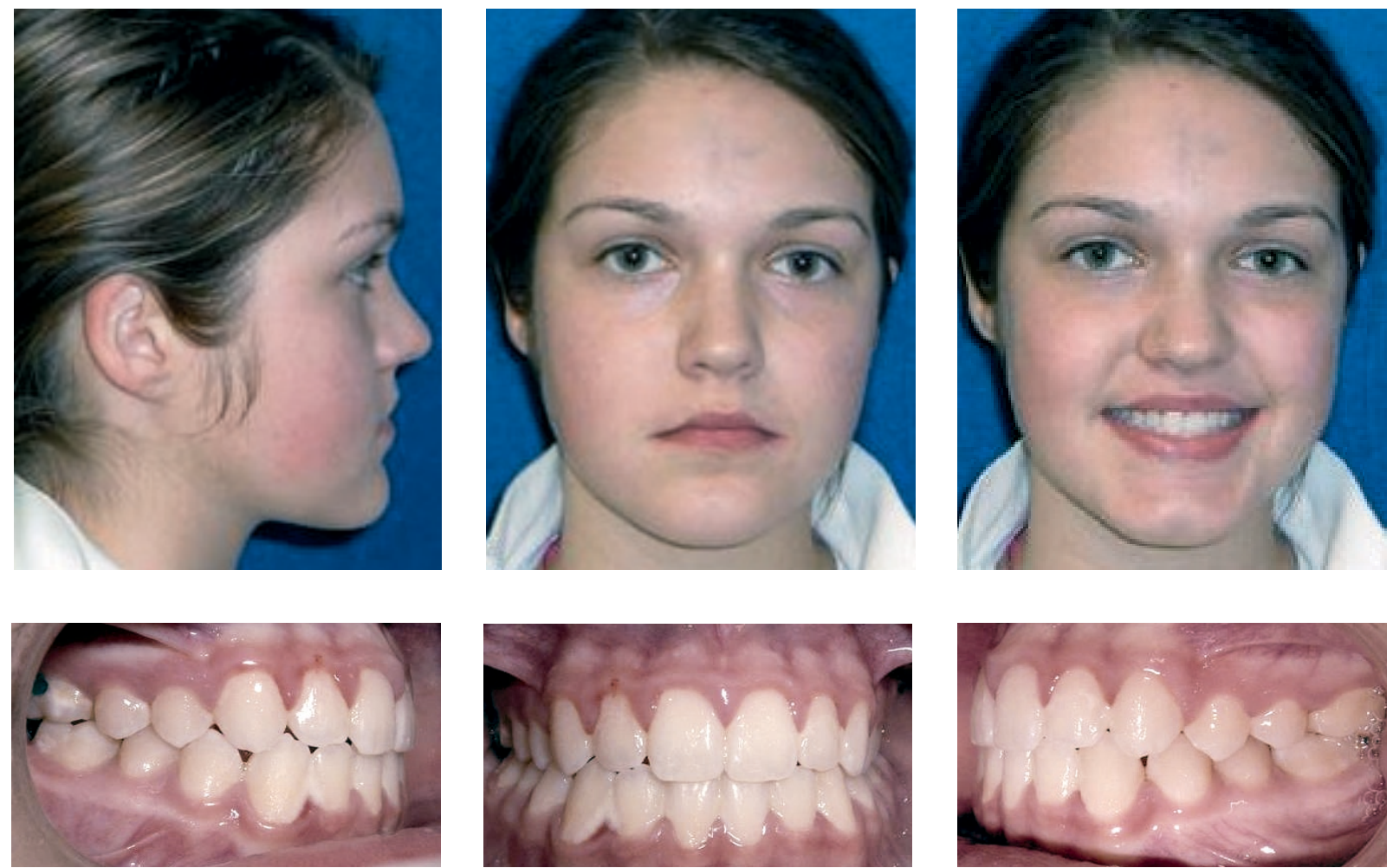

FIGURA 9 - Fotografias extrabucais e intrabucais, um ano após tratamento, mostrando estabilidade do resultado.

com aparelho fixo, extração dos primeiros molares inferiores e mecânica de elásticos com direção de Classe III. A condução correta do tratamento resultou na finalização observada na figura 8 .

Seria ilusório, no entanto, pensar que todos os casos têm caminho semelhante a esse. Assim, é preciso levar em conta também os riscos que cercam a implementação do protocolo discutido neste trabalho. Dentre eles, é preciso considerar a chance de um prognóstico incerto, a necessidade de um retratamento futuro, que incluiria até mesmo intervenções cirúrgicas, o tempo prolongado de tratamento e um desequilíbrio na relação custo/benefício.

O sucesso do caso poderia ser creditado à manipulação dos vetores e direção do crescimento e ao adequado controle da mecânica. As evidências clínicas aqui ilustradas levam, então, a um questionamento importante.

\section{Há possibilidade de se controlar o cresci- mento?}

Tradições seculares e mesmo hábitos culturais modernos comprovam o emprego de recursos ortopédicos para alterar a forma de partes do corpo (Fig. 10, 11).

Aparelhos ortopédicos utilizados na Medicina - como, por exemplo, o Milwaukee Brace - também são capazes de provocar alterações esqueléticas significativas.

Um trabalho clássico da literatura ortodônti$\mathrm{ca}^{20}$ permite ver mudanças significativas no complexo craniofacial de dois animais que, por 140 dias, fizeram uso de uma mentoneira. Ao final do periodo, os animais foram sacrificados, juntamente com os dois do grupo controle, permitindo a comparação. Foram observadas grandes diferenças entre os grupos, no tocante à forma da mandíbula 

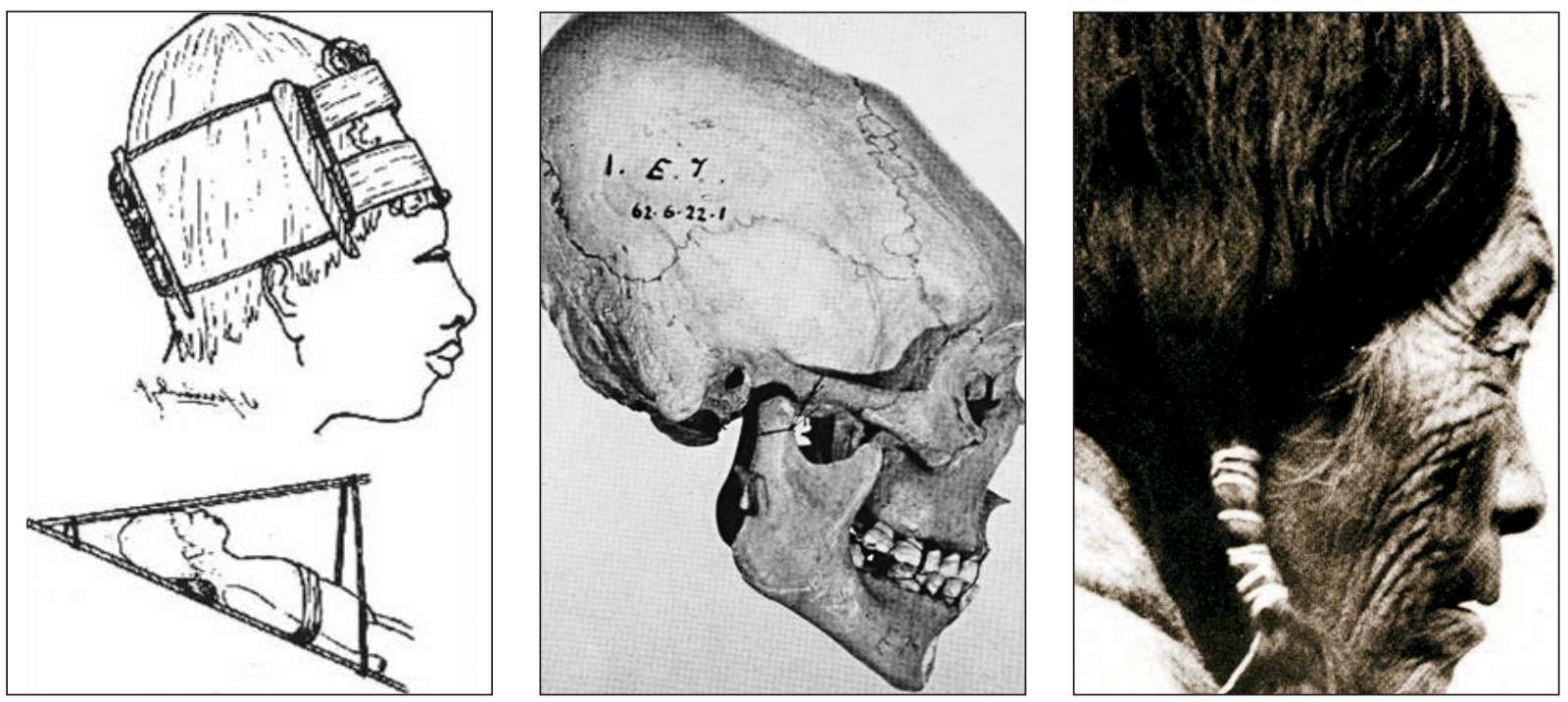

FIGURA 10 - Deformação do crânio induzida em indígenas colombianos (Fonte: PÉRES-MARTINEZ²2).

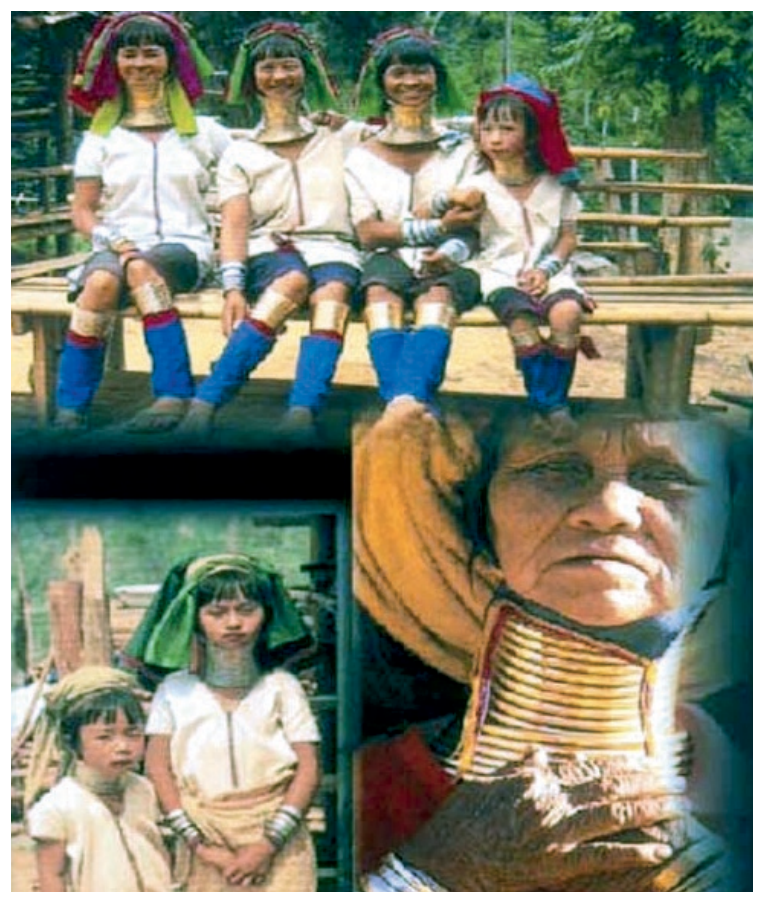

FIGURA 11 - Alongamento do pescoço induzido através de anéis metálicos em mulheres da Tailândia.

e ao vetor de crescimento (Fig. 12).

Outro estudo demonstrou alterações relevantes na forma de ossos longos, como conseqüência da compressão a que foram submetidos ${ }^{25}$ (Fig. 13).
Trabalhos como esses permitem concluir que a quantidade de crescimento pode estar predeterminada geneticamente, mas o vetor/direção e padrão do mesmo podem sofrer alterações ambientais - em nosso caso, a aplicação de forças préestabelecidas e criteriosamente selecionadas.

Que conduta utilizar, então, na abordagem não-cirúrgica da Classe III, com chances de um bom resultado?

É o que propomos a seguir, de forma didática, dada a complexidade do tema.

\section{PROTOCOLO DE TRATAMENTO NÃO-CIRÚRGICO DA CLASSE III}

A abordagem não-cirúrgica da Classe III implica em uma seqüência de cuidados específicos, a saber:

1) diagnóstico;

2) comunicação;

3) intervenção precoce;

4) expansão maxilar;

5) ortopedia;

6) controle do espaço de Leeway;

7) mecânica ortodôntica; 

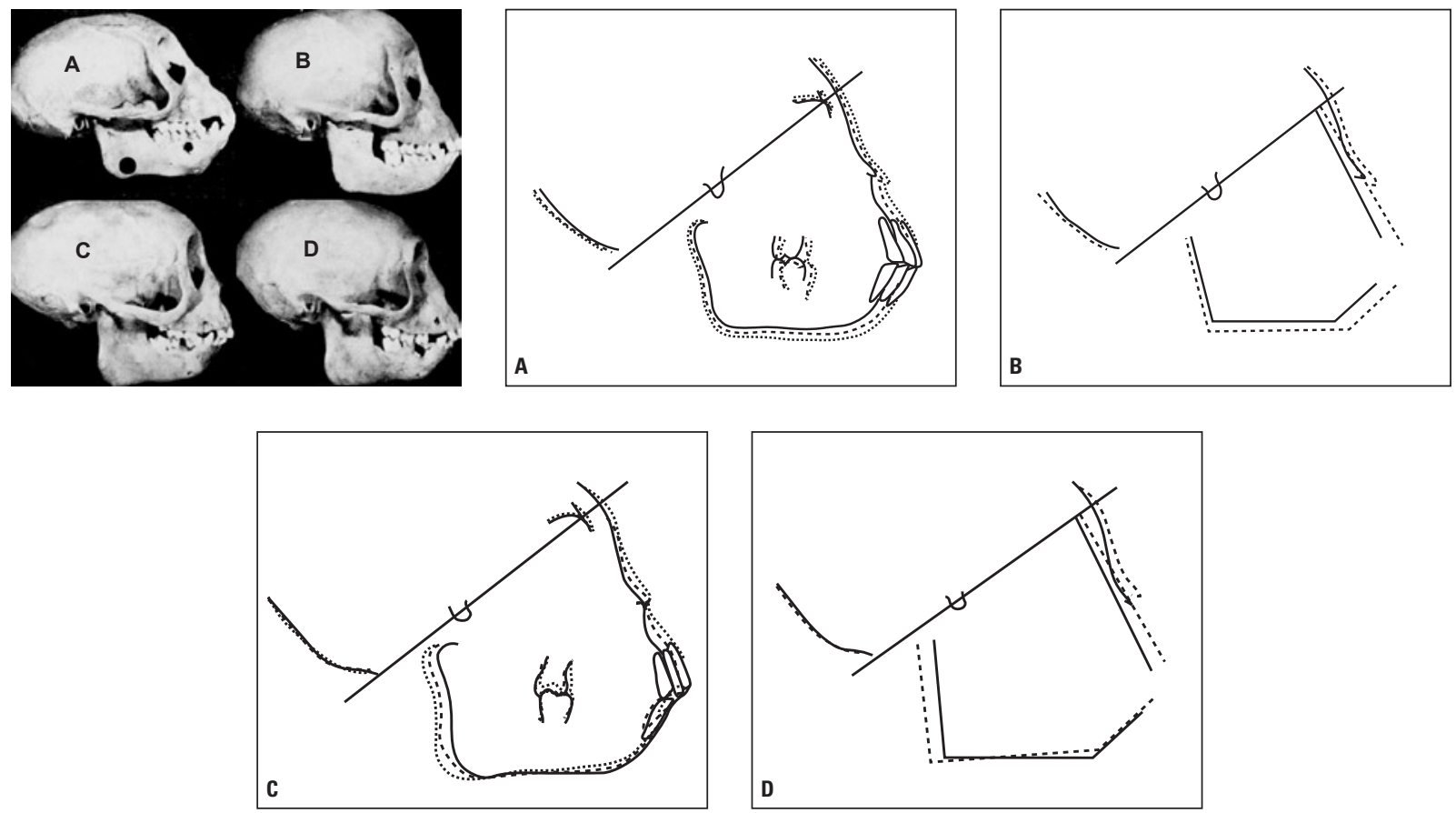

FIGURA 12 - Vista lateral acompanhada dos traçados realizados no estudo que manteve uma mentoneira fixa por 140 dias em dois macacos (C, D). 0s animais A e B, foram utilizados como controle (Fonte: JANZEN, BLUHER ${ }^{20}$ ).

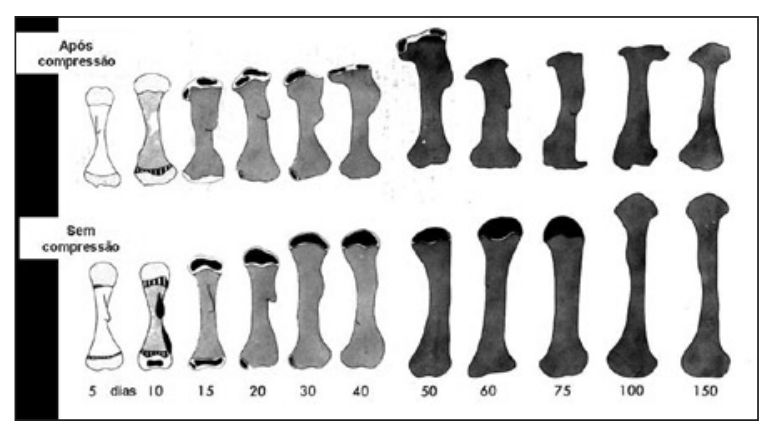

FIGURA 13 - Representação dos ossos longos utilizados no estudo, grupo de estudo e grupo controle, com e sem compressão, respectivamente (Fonte: MONSON, FELTS25.

8) finalização;

9) contenção;

10) avaliação do tratamento e reavaliação de crescimento.

\section{Diagnóstico}

O ortodontista deve se cercar de todos os cuidados para que o paciente seja diagnosticado com precisão. $\mathrm{O}$ estudo da face, a cefalometria e as características dentárias são rotina para o diagnóstico ortodôntico. Nos casos de portadores de má oclusão de Classe III, entretanto, torna-se imprescindivel acrescentar a essa rotina: em primeiro lugar, um diagnóstico funcional acurado, com registros precisos da oclusão cêntrica e da relação cêntrica; em segundo, um estudo hereditário que leve em consideração não somente as características faciais, cefalométricas e dentárias dos pais e, se possível, de irmãos mais velhos, mas também informações sobre eventuais intervenções já executadas em outros membros da família.

\section{Diagnóstico facial}

O exame facial de um paciente requer uma cuidadosa observação frontal e também de perfil. Tomam-se fotografias da face, com o paciente em posição natural da cabeça, ou seja, como se ele estivesse olhando para o horizonte. Essa posição se aproxima muito à do plano óptico ${ }^{36}$, em paralelo 
com a posição natural do piso.

É comum portadores de Classe III apresentarem contatos dentários prematuros, responsáveis por deslocamentos posturais significativos e indicadores de condutas clínicas específicas (Fig. 14).

Esse exame da face também traz as primeiras indicações sobre a origem da má oclusão, se uma discrepância maxilar pura, uma displasia mandibular verdadeira ou uma combinação de ambas ${ }^{37}$.

Recomenda-se que todos os registros iniciais sejam tomados com critério, em OC e RC, e utilizados para formulação do plano de trabalho.

Fotografias de frente, perfil, perfil em $45^{\circ}$ e sorriso devem seguir o padrão do Board Brasileiro de Ortodontia e Ortopedia Facial ${ }^{9}$.

\section{Diagnóstico cefalométrico}

A literatura ortodôntica está repleta de análises cefalométricas que, embora guardem entre si grande semelhança, ao mesmo tempo, apresentam especificidades que fazem de cada uma um instrumento singular. A partir de um minucioso estudo que avaliou várias dessas análises e selecionou os pontos mais significantes do conjunto, foi proposto um Wigglegram, um dispositivo gráfico que quantifica os desvios, permitindo uma visualização mais precisa dos mesmos ${ }^{1}$ (Fig. 15).

O protocolo também incluiu a análise cefalométrica de Sassouni ${ }^{37}$ que, de forma eficiente e confiável, revela as características esqueléticas de cada paciente. Ainda foram acrescentadas duas tomadas cefalométricas, também em OC e RC (Fig. 16).

Essas informações, associadas aos registros faciais e dentários, constituem uma fonte indispensável para determinação dos limites da camuflagem da má oclusão. Conforme referência anterior, a camuflagem no tratamento da Classe III inclui uma rotação no sentido horário da mandíbula, uma proclinação dos incisivos superiores e uma retroinclinação dos incisivos inferiores. Esse processo deve ser determinado pela possibilidade de um selamento labial passivo (Fig. 14, 15, 16).

\section{Diagnóstico dentário}

O diagnóstico dentário deve incluir radiografias panorâmicas/periapicais e modelos de estudo, sendo, muitas vezes, necessário registrar a mordida em articulador semi-ajustável.

As análises intra-arcos determinam o grau de apinhamento/espaçamento, as giroversões, a severidade da curva de Spee, a ausência congênita de elementos dentários ou a presença de supranumerários e fornecem as medidas mesiodistais dos dentes, a serem utilizadas na análise de uma eventual discrepância de Bolton ${ }^{5,10,31,38}$.

A análise interarcos leva em consideração a relação maxila/mandíbula em todas as dimensões transversal, póstero-anterior e vertical - o que permite mensurar a severidade do desvio em todos os planos de observação (Fig. 17). O caso finalizado, com extrações de primeiros molares inferiores pode ser observado na figura 18 .

\section{Diagnóstico funcional}

Em pacientes portadores de má oclusão de Classe III, torna-se imprescindível o diagnóstico funcional. Deve-se detectar as prematuridades, sobretudo em pacientes no início da transição dentária, de decídua para permanente. Esses desvios podem tornar assimetrias faciais transitórias em definitivas. Também é comum existirem contatos prematuros como elementos causadores de uma postura mais anterior da mandibula, as pseudoClasses III, que se transformam num verdadeiro ativador de Classe II, natural, iatrogênico e permanente.

Estando as prematuridades presentes na dentadura decídua, aconselha-se desgastes oclusais, para que uma melhor função seja estabelecida desde cedo. É importante que se analise cada caso individualmente e, de acordo com o grau de severidade, se estabeleça a conduta mais adequada.

\section{Diagnóstico hereditário}

Em Odontologia, as más oclusões são os problemas de origem hereditária mais comuns ${ }^{35}$, 

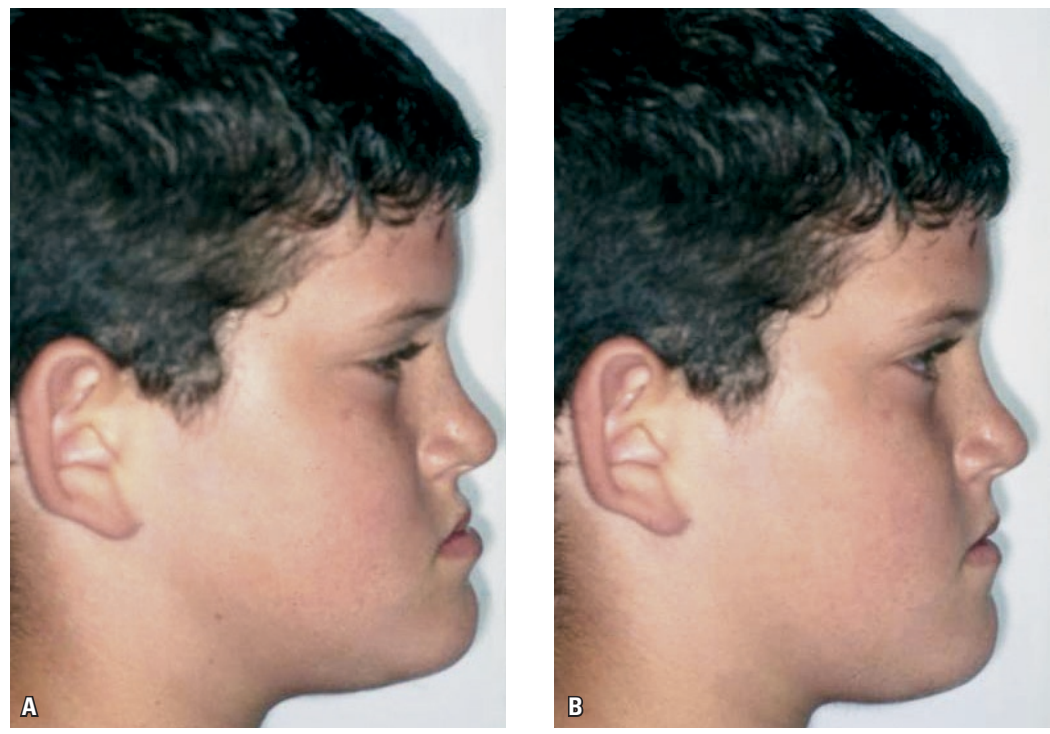

FIGURA 14 - Análise facial pré-tratamento: A) em oclusão cêntrica e B) em relação cêntrica.

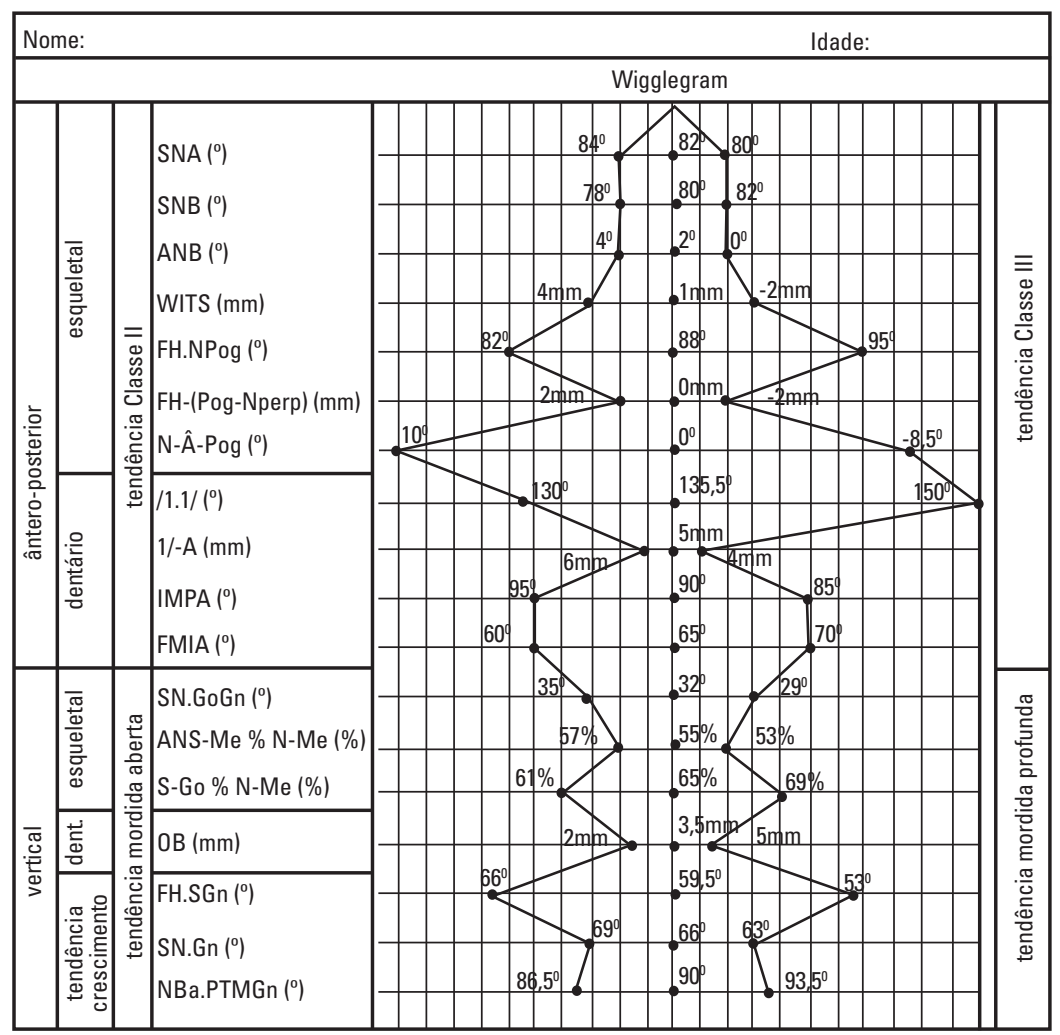

FIGURA 15 - Wigglegram - estudo cefalométrico que agrega medidas de diversas análises num diagrama que proporciona vizualização facilitada das medidas de cada paciente (Fonte: AMARAL'1).
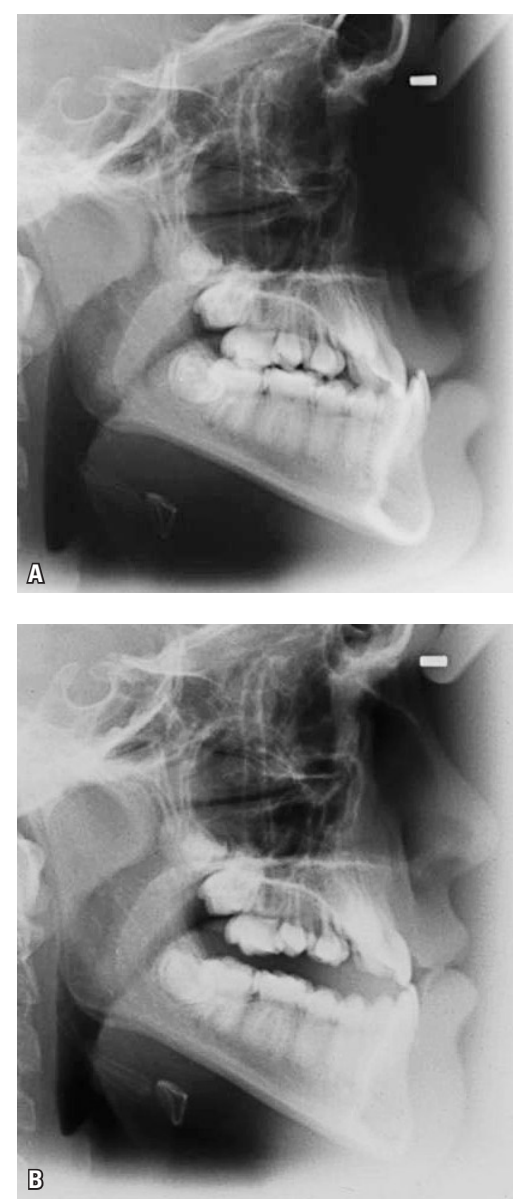

FIGURA 16 - Radiografias cefalométricas tomadas em oclusão cêntrica $(\mathbf{A})$ e relação cêntrica $(\mathbf{B})$. 

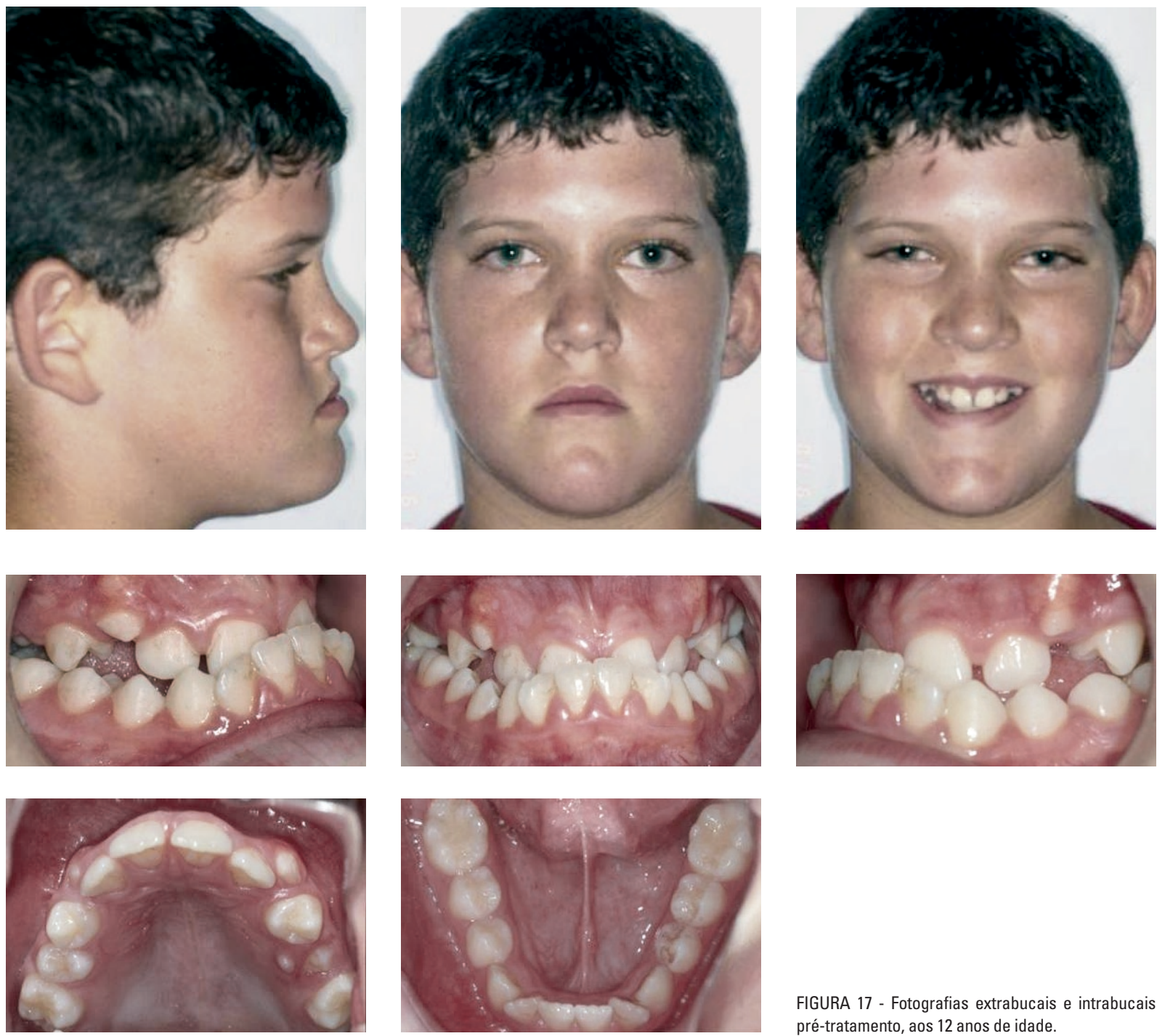

FIGURA 17 - Fotografias extrabucais e intrabucais pré-tratamento, aos 12 anos de idade.

o que nem sempre é levado em consideração.

Normalmente, o estudo da hereditariedade vem em segundo plano. Trata-se, no entanto, de um campo de alta relevância, sobretudo em más oclusões severas, com componentes esqueléticos desviados dos padrões da normalidade ${ }^{6,17}$.

$\mathrm{Na}$ literatura da área, estudos importantes são atribuídos a Krogman ${ }^{22}$. Em relação aos fatores hereditários, o autor lembra que, assim que uma criança nasce, logo se iniciam as especulações sobre eventuais semelhanças com seus familiares. Com quem se parece o bebê? Segundo o estu- dioso, a alegria de se identificar semelhanças num bebê é um reconhecimento do fato de que traços físicos são herdados, têm base genética e seguem uma linha familiar.

Outros pesquisadores têm pareceres mais contundentes sobre o assunto, ressaltando que as observações hereditárias, através de exame detalhado dos registros obtidos entre familiares, representam a melhor opção para se aumentar a confiabilidade dos dados recolhidos sobre o paciente ${ }^{16}$.

Brodie $^{11}$, desde 1941, defendia o estudo das características familiares como uma forma possível 

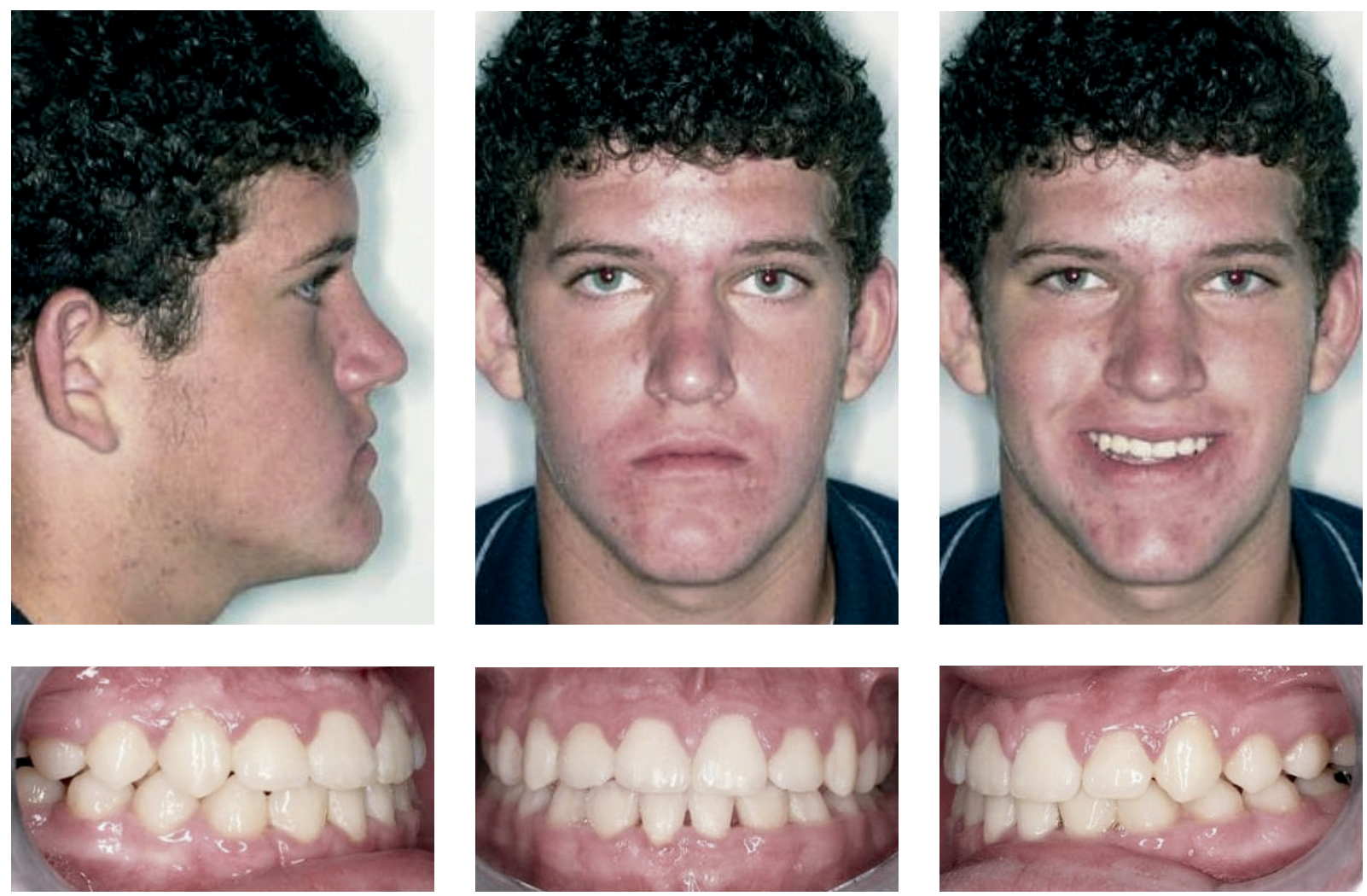

FIGURA 18 - Fotografias extrabucais e intrabucais aos 15 anos de idade, pós-tratamento realizado com protração maxilar, ancorada em mentoneira de Hickham, aparelho ortodôntico fixo total e extração dos primeiros molares inferiores.
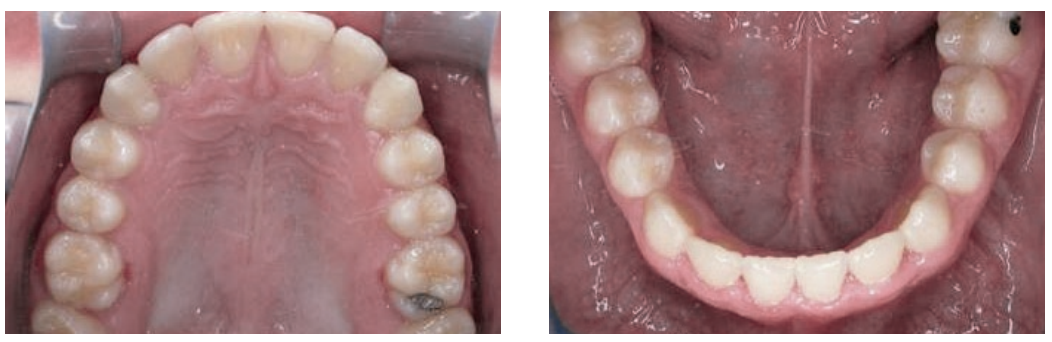

de se distinguir indivíduos com padrão de crescimento mais favorável de outros menos favoráveis.

Mais recentemente, a literatura foi enriquecida com estudos de Mossey $^{27}$, que identificaram os componentes hereditários com maior probabilidade de se relacionarem com as más oclusões. São eles: tamanho da maxila, tamanho da mandíbula, relação das bases ósseas, forma dos arcos dentários, número, forma e tamanho dos dentes, morfologia dos tecidos moles e atividade muscular.

O autor prossegue com indicações das medidas cefalométricas mais correlacionadas com a here- ditariedade. Dentre as medidas angulares, estão o ângulo goníaco, o ângulo facial, o ângulo do eixo $\mathrm{Y}$, o SNA, o SNB e o ANB. As medidas lineares incluem o tamanho do corpo da mandíbula, a altura do ramo ascendente, a altura facial total, a altura facial inferior, os comprimentos da maxila e da mandíbula, a sobremordida e a sobressaliência.

Elencados esses componentes, é possivel se categorizar a oclusão. Se há harmonia entre eles, a oclusão é considerada normal ${ }^{2,3}$, caso haja desvios do padrão ideal, estará, então, caracterizada a má oclusão com possível origem hereditária. 
A influência genética nos distúrbios craniofaciais, embora comprovada, também é contestada por aqueles que não acreditam ser possível tratar ou minimizar seu efeito. A possibilidade de uma intervenção em idade precoce, com base nas indicações reveladas pelos exames dos pais, porém, é uma manipulação dos fatores ambientais através da Ortodontia. O fato de os pais possuírem um distúrbio semelhante já caracteriza um incentivo para a realização do tratamento.

É preciso ressalvar, no entanto, que não se consegue identificar o percentual específico da influência do meio ambiente e o da genética no complexo craniofacial e, por isso mesmo, também não se pode determinar o grau de atuação desses fatores nos pais. Qual seria o quadro apresentado por estes se tivessem sido submetidos a um tratamento adequado no momento certo? A severidade de sua má oclusão seria a mesma?

Mesmo assim, uma análise dos pais pode contribuir para identificar medidas que possibilitem uma manipulação das variáveis.

\section{Comunicação}

Feitos todos os estudos capazes de contribuir para a escolha de uma conduta adequada, vem a fase de esclarecimentos ao paciente e à família. Nesse momento, é essencial um diálogo franco, centrado em dados e probalidades. Três pontos básicos devem ser enfatizados: primeiro, a incerteza dos resultados, mesmo que tenham sido estabelecidas metas com probabilidade de sucesso; segundo, o prognóstico obscuro, pois tudo dependerá do desenvolvimento do paciente; e terceiro, o possível retratamento, uma vez finalizado o crescimento, envolvendo desde um simples renivelamento até uma intervenção cirúrgica.

Também é necessário deixar claro que o tratamento requer alto nível de cooperação e que sua duração pode exceder a de períodos básicos de uma terapia ortodôntica. Trata-se, afinal, de um processo em que se vai observar e acompanhar o crescimento e desenvolvimento do paciente.

\section{Intervenção precoce}

O glossário da Ortodontia, pelo menos em nosso idioma, não oferece um termo que designe com mais propriedade um momento muito significativo na intervenção e possível interceptação de uma Classe III. Precoce, uma das possíveis traduções do termo "early", do Inglês, está longe de ser adequada para caracterizar essa época da intervenção. Fique claro que intervenção precoce, aqui, não se refere a um tratamento feito antecipadamente, mas a uma conduta clínica realizada no momento indicado.

Feita a ressalva ao termo, passamos a descrever, então, o que ocorre. É nesse período que começa a se desenhar a harmonia ou a desarmonia da oclusão ou de uma má oclusão nos planos transversal, póstero-anterior e vertical.

Nos casos da Classe III, em primeiro lugar, sugere-se a intervenção no sentido transversal, até mesmo porque a maxila, normalmente, necessita de uma expansão para se adequar à mandíbula.

Ressaltamos, mais uma vez, a importância de que, antes do início do trabalho clínico, todos os dados recolhidos já estejam analisados e o diagnóstico amplamente definido. É imprescindivel, também, um entendimento integral das condições apresentadas no caso, além do "contrato" de cooperação do paciente e participação da família para que as metas traçadas sejam atingidas.

É durante a fase de dentadura mista que acontecem as maiores transformações morfológicas do indivíduo e, por isso mesmo, deve ser enfatizada a utilização correta, nesse período, dos procedimentos interceptativos.

\section{Expansão maxilar}

No conjunto de procedimentos, a expansão rápida da maxila (ERM) torna-se fundamental para o estabelecimento do equilíbrio transversal da oclusão.

Um estudo clássico da literatura ortodôntica ${ }^{21}$ revela que não só a expansão dentária e da base óssea pode ser alcançada com sucesso, mas também o aumento contínuo da capacidade respiratória, 
decorrente da expansão da cavidade nasal. Esse é um dos fatores primordiais nas correções da Classe III: uma melhor função respiratória pode, com certeza, trazer grandes benefícios para o desenvolvimento da face média.

Outro benefício é a associação do procedimento da ERM com a Ortopedia.

\section{Ortopedia}

Associado à expansão maxilar, o tracionamento da maxila através de aparelhos selecionados resulta em benefícios para a correção das deficiências maxilares tão características da Classe III.

Ainda não existe um consenso sobre os benefícios da associação concomitante da ERM com a protração ortopédica da maxila. Acredita-se, entretanto, que uma atividade celular intensa nas suturas, oriunda das ERM, pode proporcionar resultados mais expressivos a essa intervenção.

\section{Que aparelho usar?}

Diversos tipos de máscaras faciais são encontrados no mercado. A literatura não apresenta estudos que dêem a qualquer uma delas um status definitivo de mais ou menos eficiente. Acreditase que o conforto do paciente e a habilidade do profissional no manuseio do aparelho são variáveis importantes para a escolha. A figura 19 mostra dois tipos de máscaras faciais pré-fabricadas e facilmente ajustáveis.

Também a mentoneira de Hickham é capaz de propiciar resultados positivos (Fig. 20). Tratase de um aparelho de confecção personalizada, ainda que simples, que tem sido bem aceito pelos pacientes. Mostra-se mais estável, principalmente durante o sono.

O processo da protração é amplamente descrito na literatura ${ }^{30,39}$. O protocolo adotado pelos autores do presente estudo pouco difere do referenciado. Recomenda-se um mínimo de 16 horas diárias de uso do aparelho escolhido e uma força de cerca de 400 a 500 gramas de cada lado.

É importante se observar o ponto de aplicação da força, bem como sua direção. Pode-se utilizar um disjuntor, com ou sem cobertura oclusal de acrílico. Cada caso deve ser analisado cuidadosamente e a escolha deve basear-se na necessidade do paciente, sua idade dentária e padrão de crescimento.

A qualquer dos dois tipos de aparelho são acoplados ganchos vestibulares para ancoragem dos elásticos ao nível dos caninos. Essa conduta clínica produz resultados eficazes, dentre os quais uma protração esquelética da maxila - mínima, porém importante -, uma protração dentária do arco superior e uma rotação horária da mandíbula, movimento principal no processo da camuflagem da Classe III.

A duração da fase de protração varia de 8 a 10 meses, aproximadamente. Após esse período, indica-se o controle através de uma mentoneira soft. (Fig. 21). O emprego dessa mentoneira deve ser acompanhado de uma placa prensada de acrílico no arco superior, tipo Essix, com espessura de 1 a $2 \mathrm{~mm}$, que minimiza uma possível compressão do disco articular na ATM.

Dentre as muitas controvérsias do tratamento da Classe III, está o efeito da terapia na articulação temporomandibular. A literatura apresenta conclusões conflitantes. Alguns estudos ${ }^{23,28}$ correlacionam desordens temporomandibulares (DTM), transformações anatômicas nos côndilos e na cavidade glenóide com o uso de mentoneiras.

Outros estudos, no entanto, não conseguiram detectar essa correlação, concluindo que as DTM's acontecem independentemente dos aparelhos empregados no tratamento da Classe III $^{4,12,13,14,34,40}$.

\section{Controle do espaço de Leeway}

Parece haver um consenso em torno da importância da presença dos segundos molares decíduos, sempre que possível, quando se inicia um tratamento ortodôntico. Um estudo que analisou o índice de extrações em tratamentos iniciados em épocas distintas comprovou a redução de extrações no grupo iniciado no período da dentadura mista tardia, dada a preservação desses espaços ${ }^{26}$. 

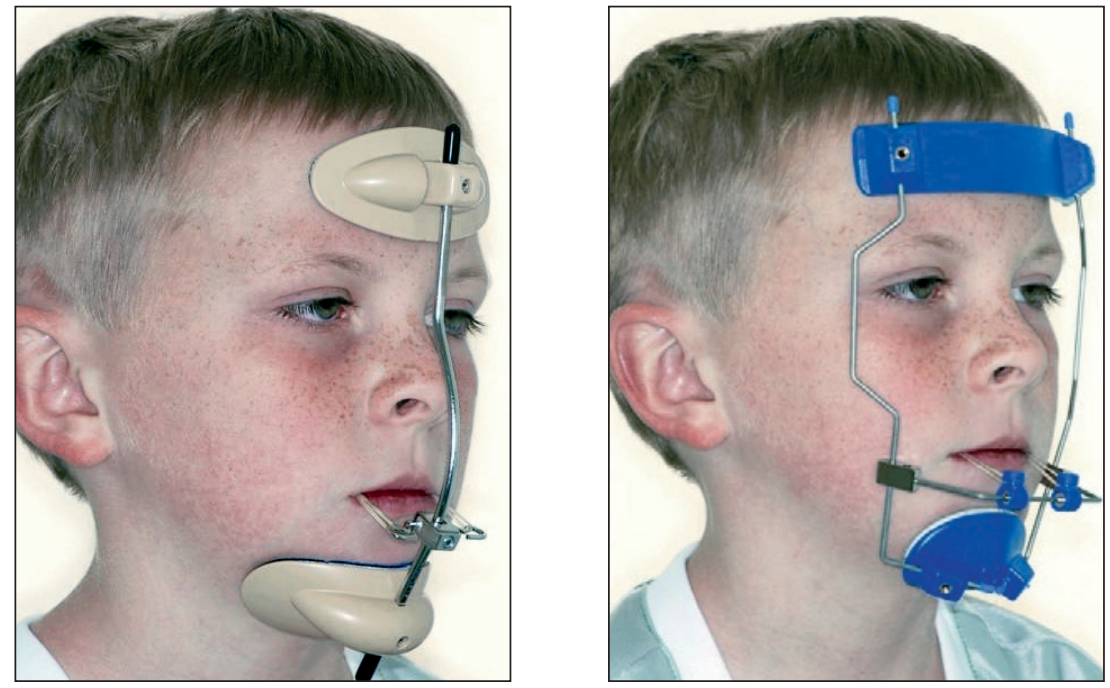

FIGURA 19 - Tipos de máscaras faciais ajustáveis para protração ortopédica da maxila.

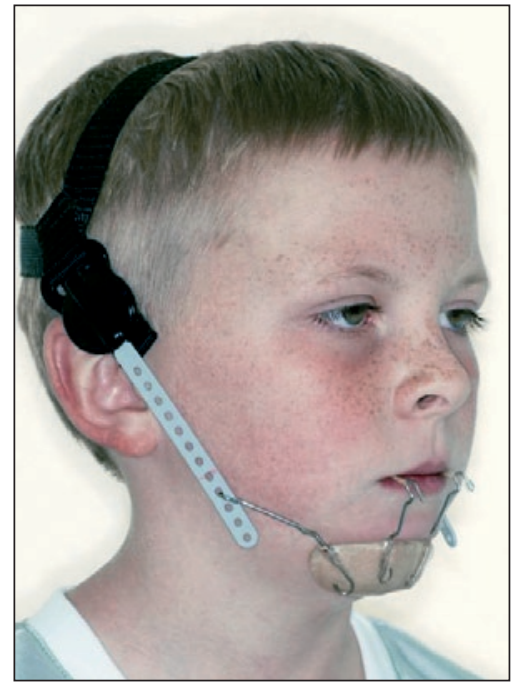

FIGURA 20 - Mentoneira de Hickham como ancoragem para protração ortopédica da maxila.

Há algum tempo, temos defendido que o espaço de Leeway tornou-se tão importante na terapêutica ortodôntica que deveria ser chamado de o espaço do ortodontista. São incalculáveis os benefícios que sua correta manipulação propiciam a uma correção ortodôntica. Não importa se o tratamento se dá em uma ou duas fases. Até mesmo aqueles que se opõem ao tratamento em duas fases não deixam de apontar a necessidade de se

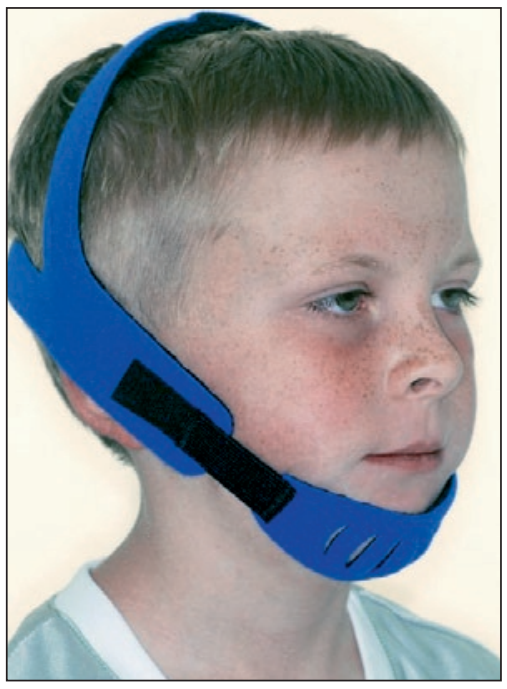

FIGURA 21 - Mentoneira soft para controle mandibular, utilizada após protração ortopédica da maxila.

aproveitar a generosidade da natureza ao nos proporcionar esse espaço.

Nas Classes III, principalmente, qualquer ganho no arco inferior é bem-vindo. A colocação de um arco lingual para preservá-lo torna-se quase mandatória.

\section{Mecânica ortodôntica}

Após todos os cuidados até aqui descritos, as 
abordagens da Classe III puramente ortodônticas, sem recurso das cirurgias ortognáticas, chegam a um momento de decisões importantes, quando o profissional é obrigado a indicar uma seqüência lógica de procedimentos, com ou sem extrações dentárias. Eles podem incluir tratamentos através de:

a) conduta mais conservadora, sem extrações;

b) conduta sem extrações associada a desgastes interproximais no arco inferior;

c) extração de primeiros pré-molares inferiores;

d) extração de segundos pré-molares superiores e primeiros pré-molares inferiores;

e) extração de um incisivo inferior;

f) extração de primeiros molares inferiores.

Cada uma dessas opções pode ser adotada, dependendo do diagnóstico e da observação dos diferentes casos. As possibilidades de um resultado compensador devem ser avaliadas observando-se a face, as relações dentárias, as relações cefalométricas, o exame funcional, a idade óssea e o exame hereditário, além do fator emocional e as expectativas do paciente/família.

Recomendamos que um set-up dentário seja apresentado durante a consulta de planejamento, uma vez que constitui um importante instrumento para definição da linha de tratamento a ser seguida.

Há vantagens e desvantagens em cada opção, como agora veremos.

Tratamento conservador sem extrações, com ou sem auxílio da redução dentária interproximal

A paciente em questão se apresentou para tratamento na Clínica de Ortodontia da PUC-Minas (Fig. 22, 23). Sua idade à época era de 9,4 anos e a queixa relatada pela família era de que "os dentes superiores estavam se virando para dentro" (sic).

A avaliação facial indicava maxila deficiente e mandíbula em protrusão. A face inferior parecia mais longa, o que poderia ser resultado de uma postura inadequada. Essa falha postural pode ser comum em pacientes que conseguem perceber uma melhora no perfil pela rotação horária da mandíbula.
Trata-se de uma defesa para aprimorar a estética facial e, conseqüentemente, elevar a auto-estima. O selamento labial era adequado. $\mathrm{O}$ exame frontal da face mostrava uma assimetria com leve desvio para a esquerda.

A avaliação dentária apontava uma Classe III de molares e caninos, com mordida profunda severa e cruzamento total dos arcos dentários. A radiografia panorâmica indicava a presença de todos os elementos dentários em diferentes estágios de desenvolvimento.

A análise de Sassouni ${ }^{36}$ revelou prognatismo severo, acompanhado de leve retrusão maxilar, resultado semelhante às conclusões do Wigglegram. $\mathrm{O}$ exame funcional não detectou desvio importante entre OC e RC. Quanto ao estudo hereditário, não se revelaram maiores preocupações.

Em síntese, a paciente foi classificada como portadora de uma Classe III esquelética, apresentando vertical normal, mordida profunda dentária e mordida cruzada total.

Apesar da severidade da má oclusão, decidiu-se por uma intervenção que pudesse minimizar seus efeitos, aguardando o término do crescimento para uma possível cirurgia. A intervenção de escolha foi uma expansão rápida da maxila através de um disjuntor de Haas, acompanhada de uma protração maxilar utilizando-se uma mentoneira de Hickham. Após essa primeira fase, o caso seria reavaliado para continuidade do tratamento ou mesmo intervenção cirúrgica pós-crescimento.

A cooperação da paciente foi tão intensa que os primeiros sinais para continuidade do tratamento com recursos unicamente da Ortodontia ficavam mais evidentes a cada dia. Nova avaliação indicava que o ritmo do crescimento diminuía. A menarca já havia ocorrido e a resposta dentoalveolar e esquelética era favorável.

O tratamento prosseguiu com a colocação de aparelho fixo total e mecânica de elásticos para mesialização do segmento posterior maxilar, com o auxílio de ancoragem proveniente da mentoneira de Hickham. A finalização se deu com o emprego 

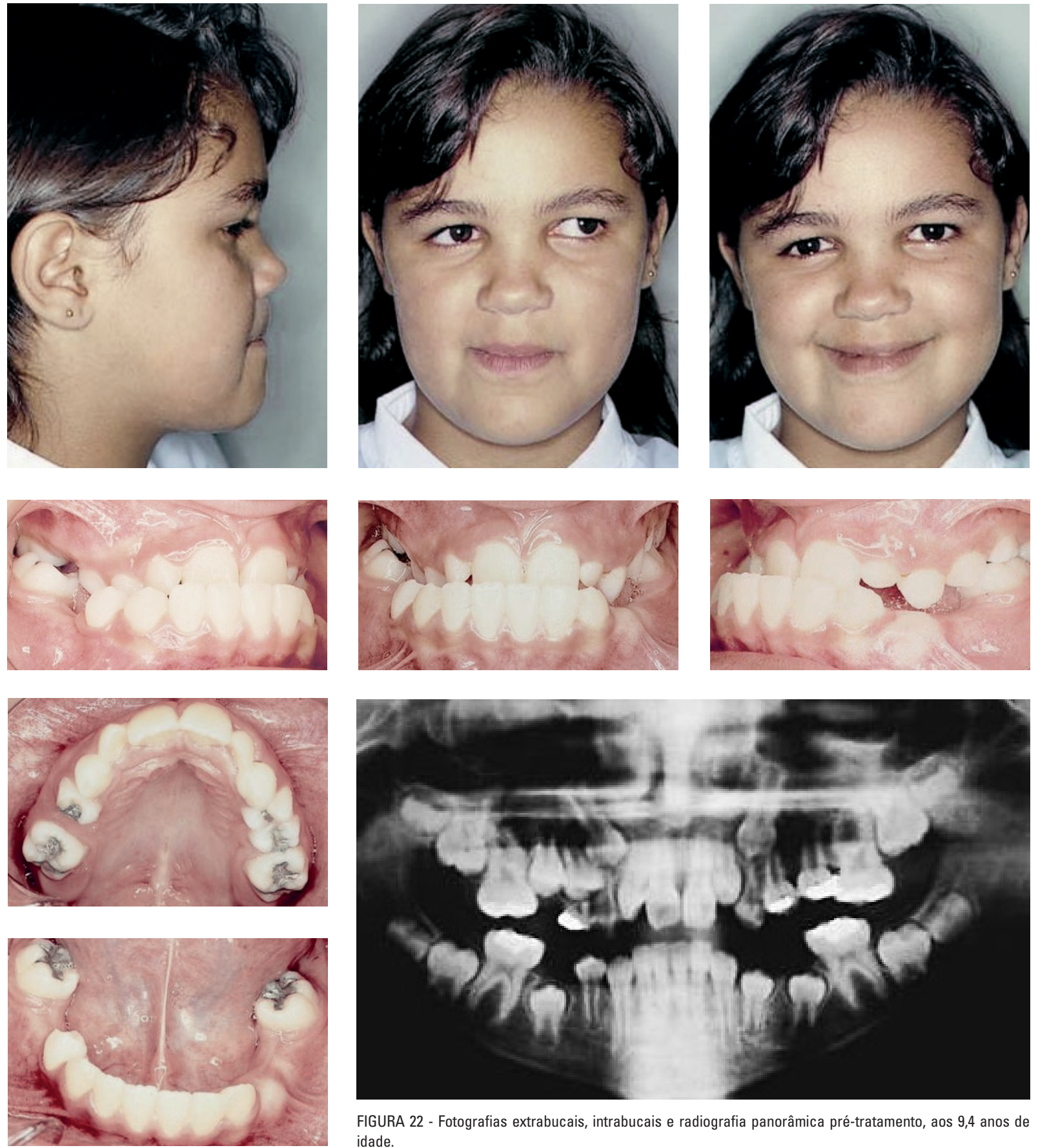

FIGURA 22 - Fotografias extrabucais, intrabucais e radiografia panorâmica pré-tratamento, aos 9,4 anos de idade.

de mecânica de elásticos com direção de Classe III, elásticos verticais e elásticos para correção da linha média. A discrepância de Bolton foi corrigida com desgastes interproximais inferiores e reconstrução estética dos incisivos superiores.

O resultado final foi surpreendente e o período de contenção também demonstrou um alto índice de estabilidade (Fig. 24, 25). 

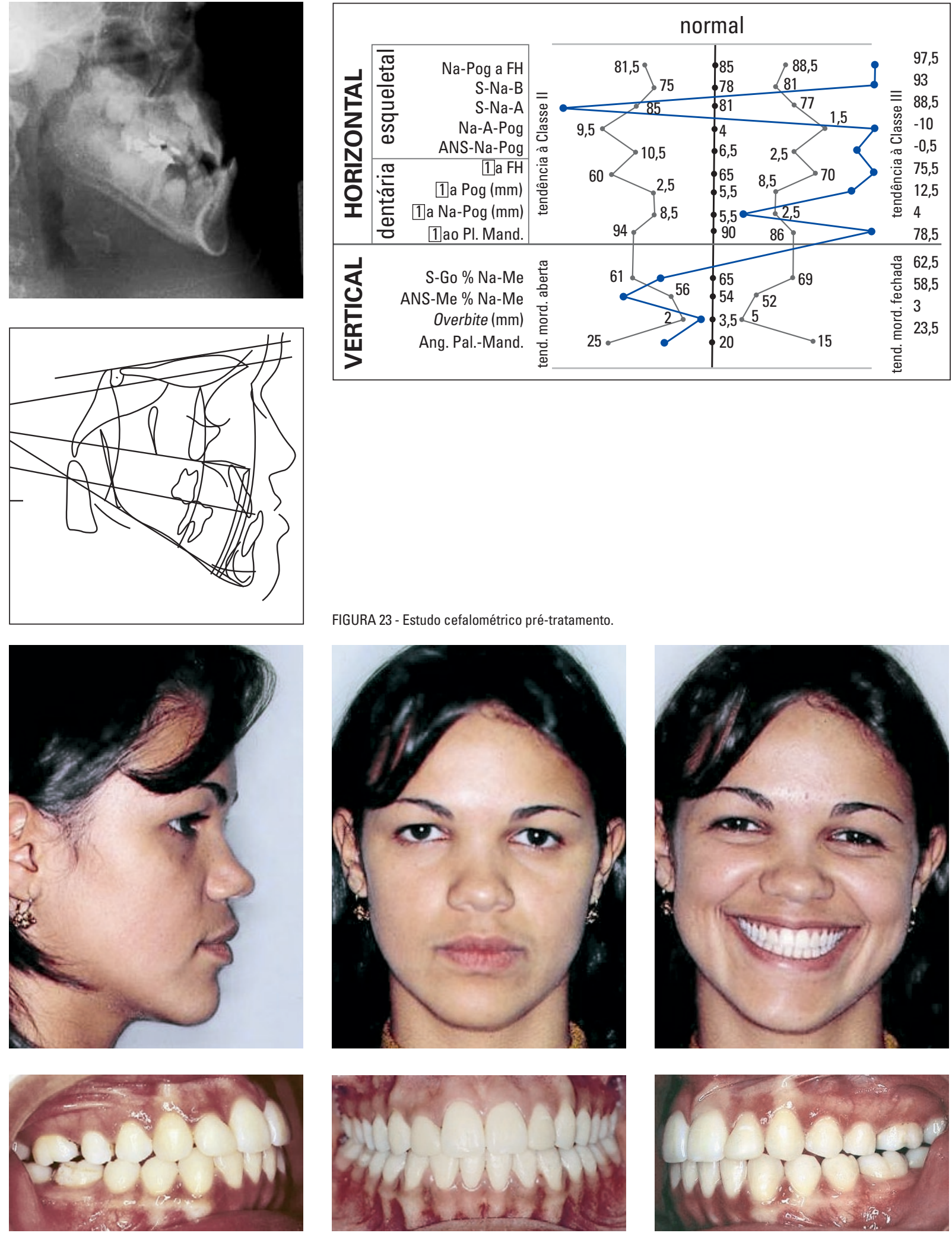

FIGURA 24 - Fotografias extrabucais e intrabucais pós-tratamento, aos 14 anos de idade. 

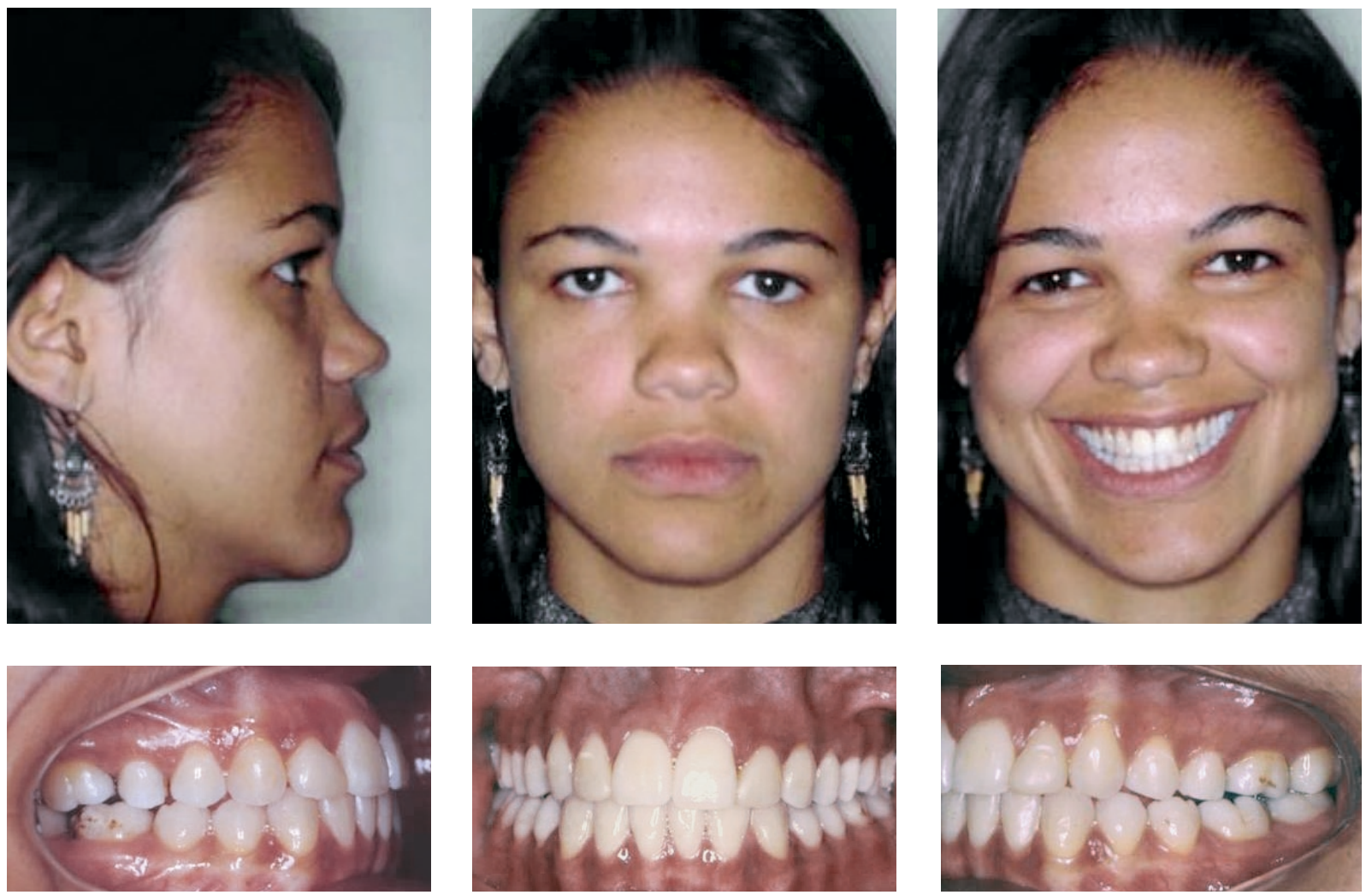

FIGURA 25 - Fotografias extrabucais e intrabucais três anos após tratamento, aos 17 anos de idade.
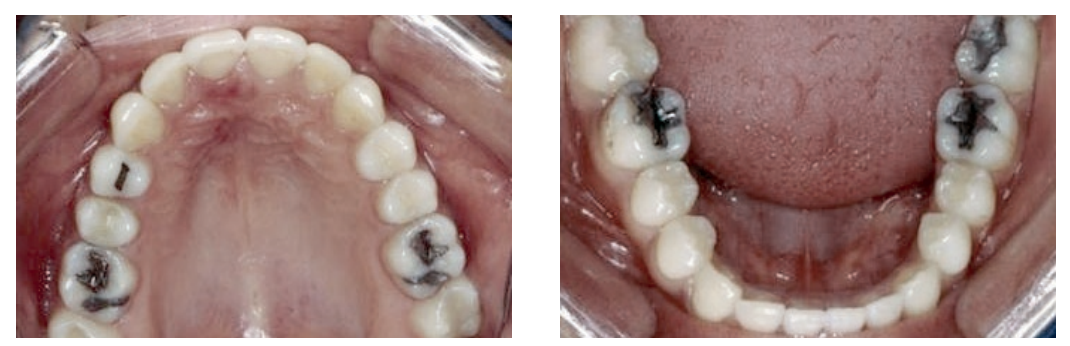

\section{Tratamento com extração dos primeiros} pré-molares inferiores

É uma conduta freqüentemente empregada, que apresenta resultados satisfatórios. Dentre suas vantagens estão: um tempo de tratamento mais adequado, uma mecânica ortodôntica sem maiores complicações e a possibilidade de uma correção duradoura, caso não ocorra um crescimento fora de proporção.

Como desvantagem, considera-se a finalização com os molares em Classe III e uma limitação de possibilidades ortodônticas futuras, caso haja um crescimento excessivo, e a necessidade de novo tratamento.

Esse padrão de extrações é mais adequado para pacientes em fase descendente de crescimento, que tenham demonstrado, durante o período de observação, um melhor controle da evolução de seu desvio esquelético.

No caso mostrado a seguir (Fig. 26-29), chegou-se a um ótimo resultado facial e uma semelhante estabilidade.

Após uma fase inicial com uma aparelho funcional de Classe III e posterior expansão rápida 

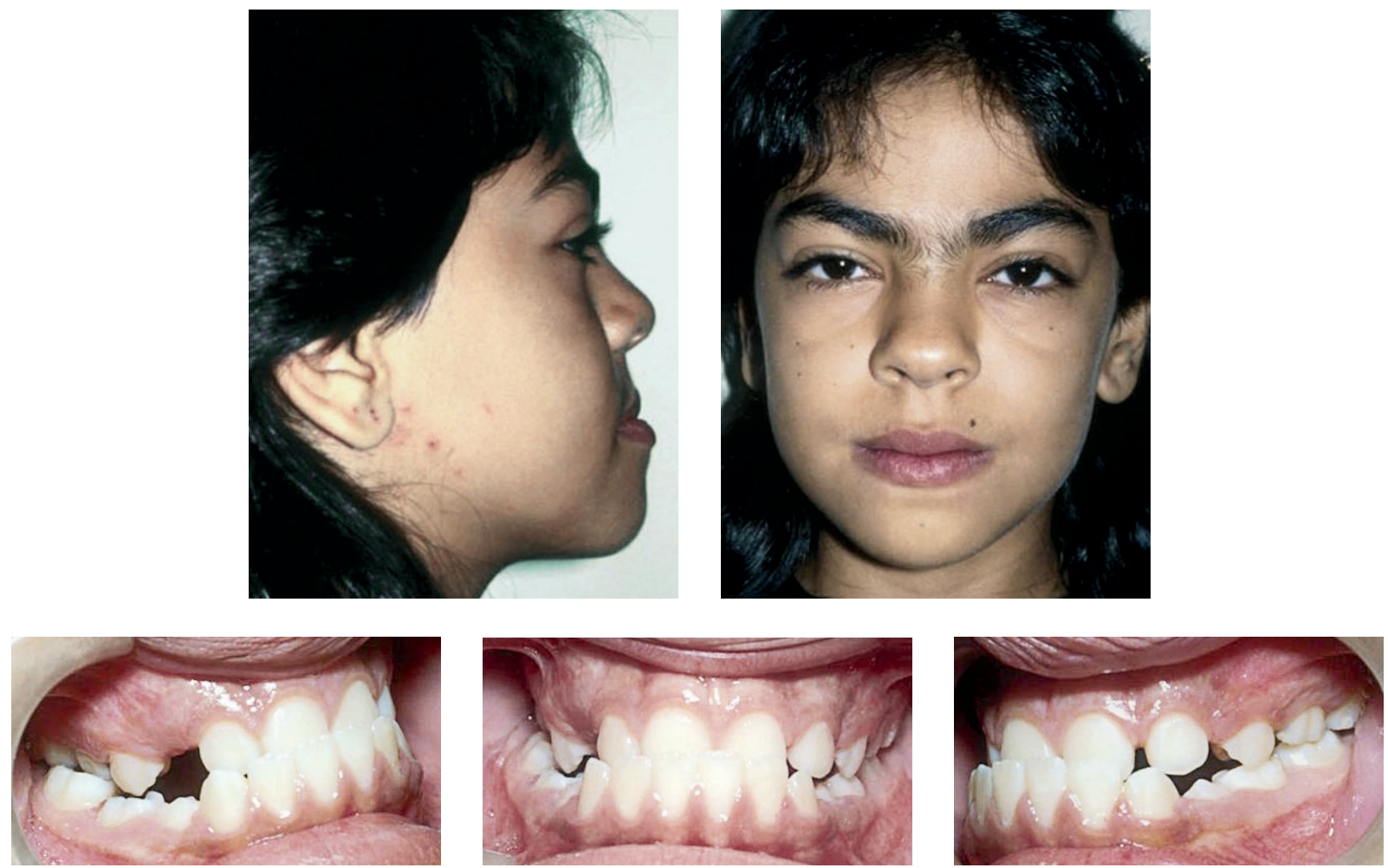

FIGURA 26 - Fotografias extrabucais e intrabucais pré-tratamento, aos 9,7 anos de idade.
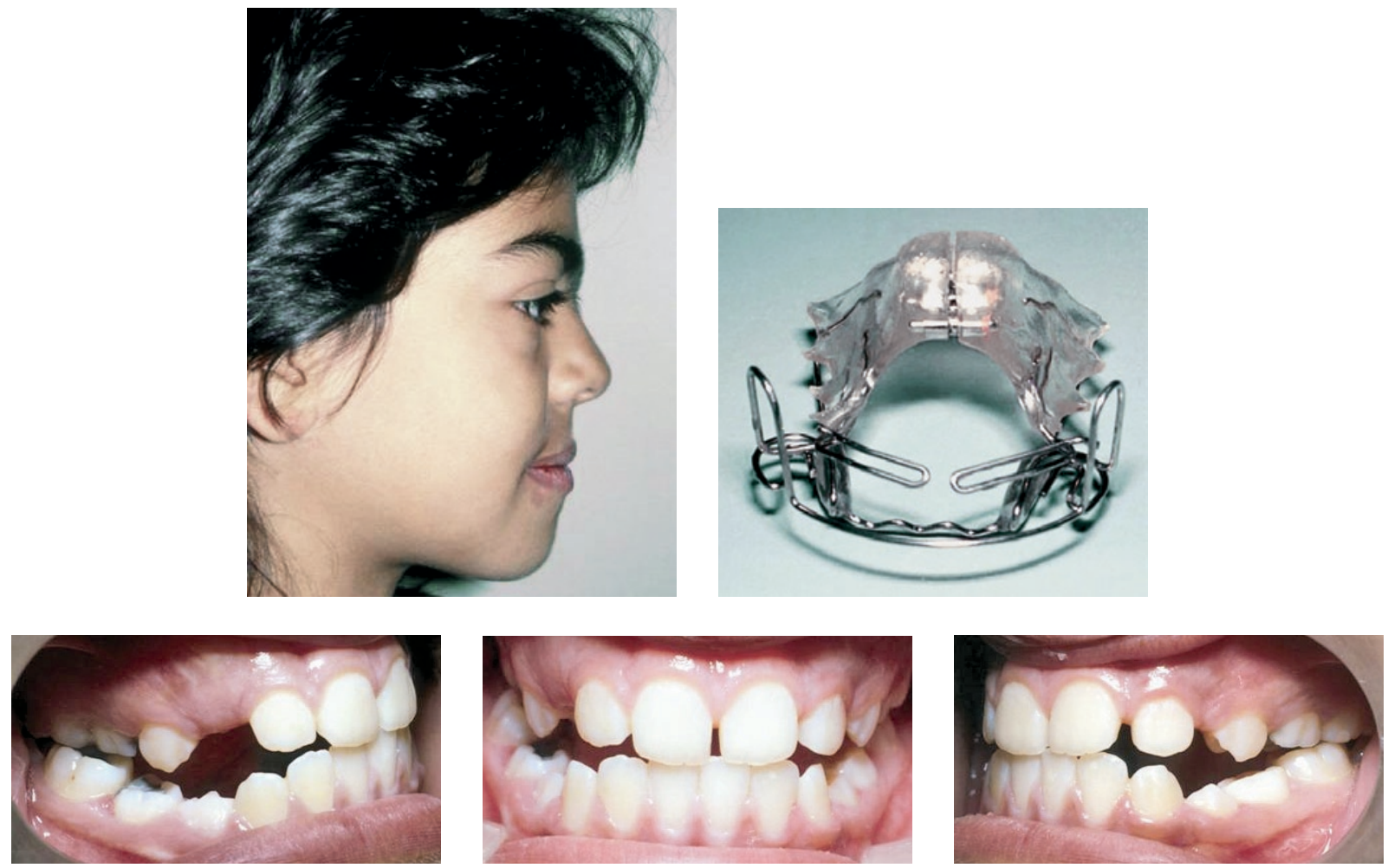

FIGURA 27 - Fotografia de perfil e intrabucais após a primeira etapa de 6 meses de tratamento com aparelho funcional de Bimler. 

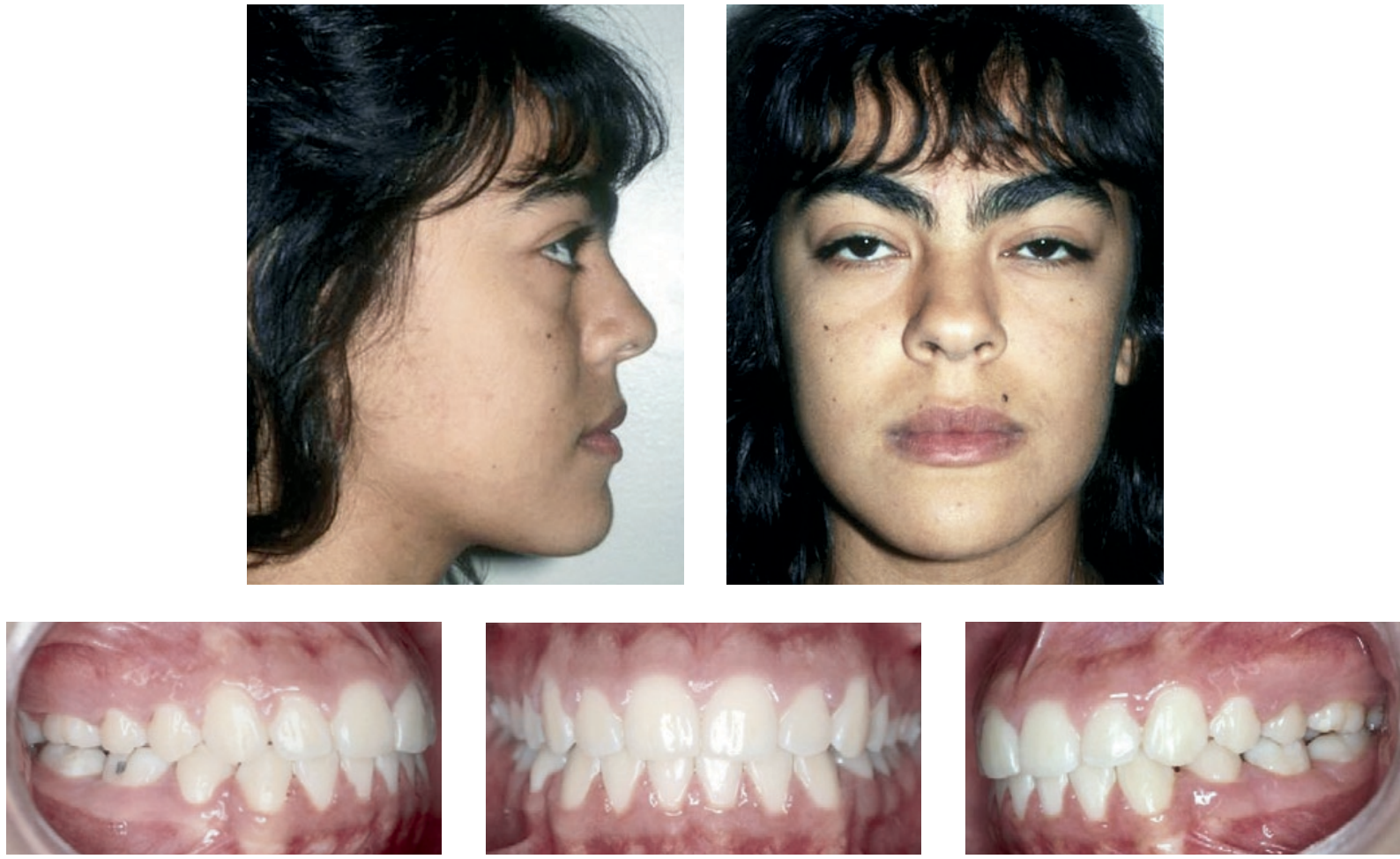

FIGURA 28 - Paciente aos 14 anos de idade, após tratamento ortodôntico com expansão rápida da maxila, mentoneira e extração dos primeiros pré-molares inferiores.
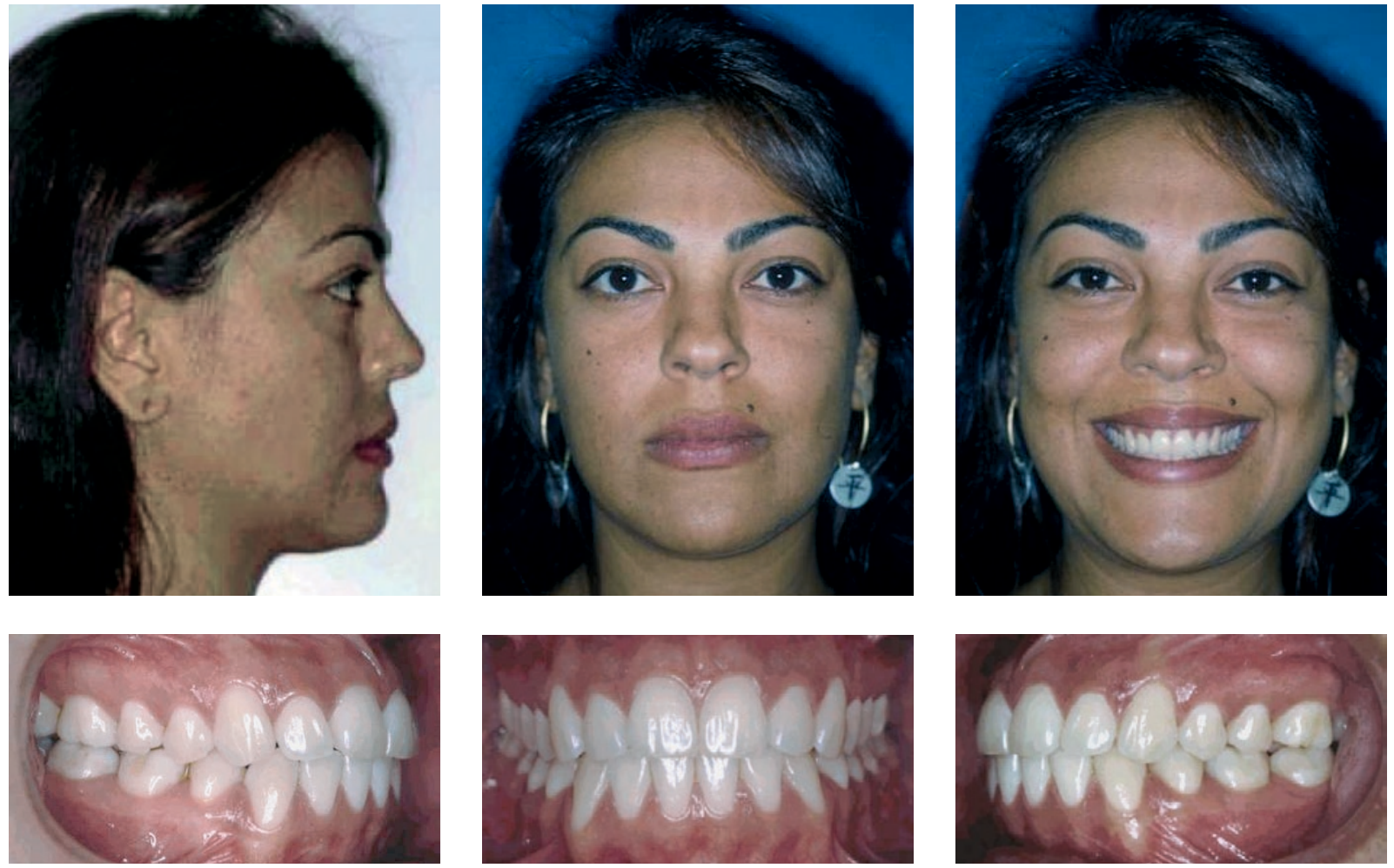

FIGURA 29 - Fotografias extrabucais e intrabucais 10 anos após o tratamento, aos 24 anos de idade. 
da maxila acompanhada de controle mandibular, optou-se pelo tratamento ortodôntico com aparelho fixo e a extração dos primeiros pré-molares inferiores.

Tratamento com extração dos primeiros prémolares inferiores e segundos pré-molares superiores

Trata-se, também, de uma conduta muito empregada, que gera resultados positivos. Em favor de sua adoção, listam-se: um tempo razoável de tratamento, uma finalização ortodôntica com relação de molares e de caninos em Classe I e a possibilidade de uma correção duradoura, caso não ocorra um crescimento mandibular exacerbado.

Contra esta opção, pesam a maior sofisticação da mecânica e uma limitação de possibilidades ortodônticas futuras, caso haja um crescimento excessivo.

Esse padrão de extrações também se destina, mais adequadamente, a pacientes em fase descendente de crescimento, com perfil facial menos comprometido, já com alguma definição de possibilidade de tratamento unicamente ortodôntico, nos quais tenha sido observado um bom controle da evolução do desvio de Classe III. O caso aqui demonstrado (Fig. 30-34) ilustra a adequação da escolha do procedimento.

A paciente, com crescimento basicamente terminado, apresentava uma relação facial e dentária com indicação para o tratamento executado.

Tratamento com extração de um incisivo inferior

Muitos clínicos utilizam esse recurso no caso de pacientes com pequena discrepância de espaço. O fato de portadores de Classe III apresentarem, usualmente, uma discrepância dentária de Bolton facilita essa decisão. Sugere-se que o procedimento seja precedido de um set-up dentário, capaz de replicar uma possível finalização para o caso.
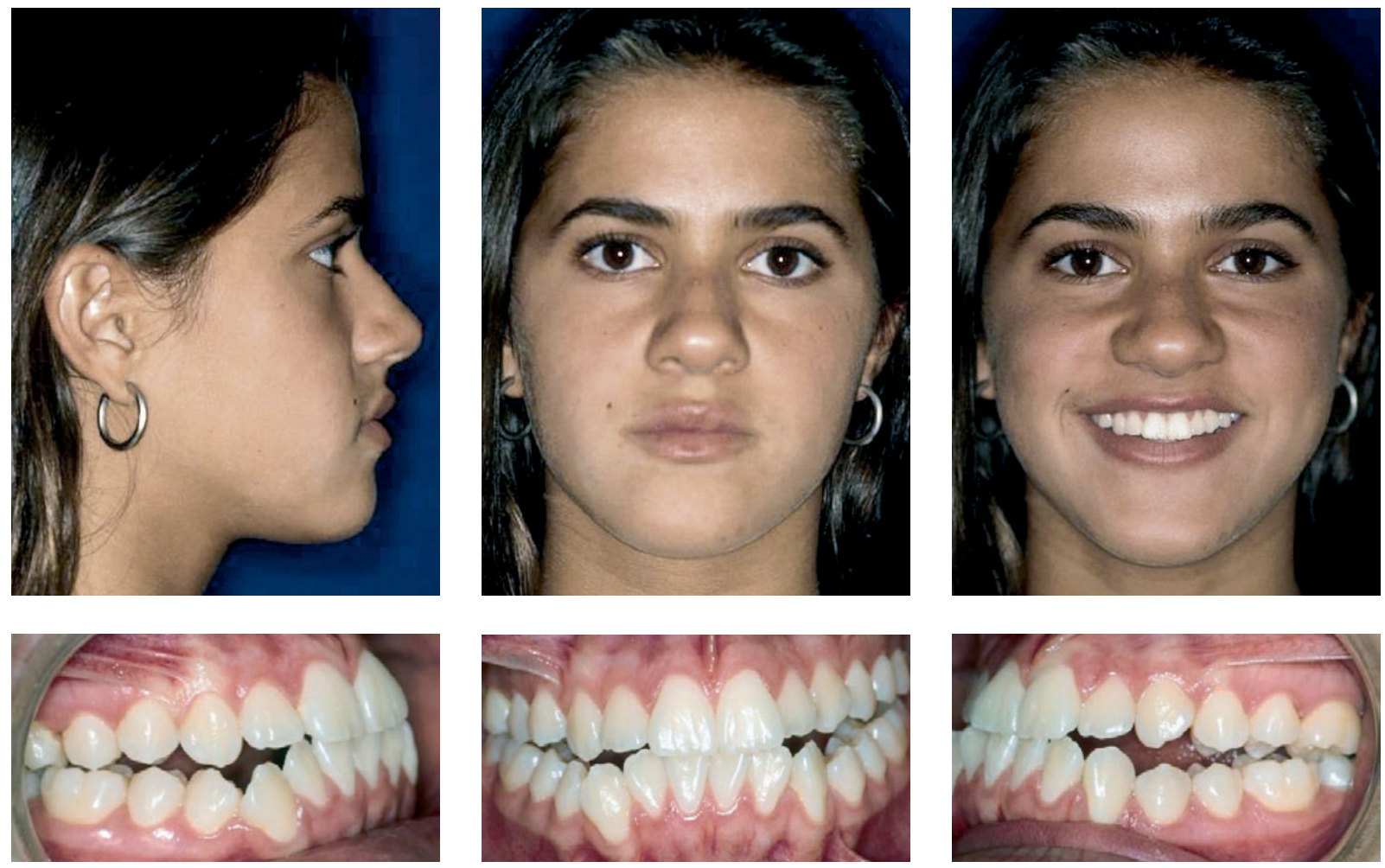

FIGURA 30 - Fotografias extrabucais e intrabucais pré-tratamento, aos 14,6 anos de idade. 

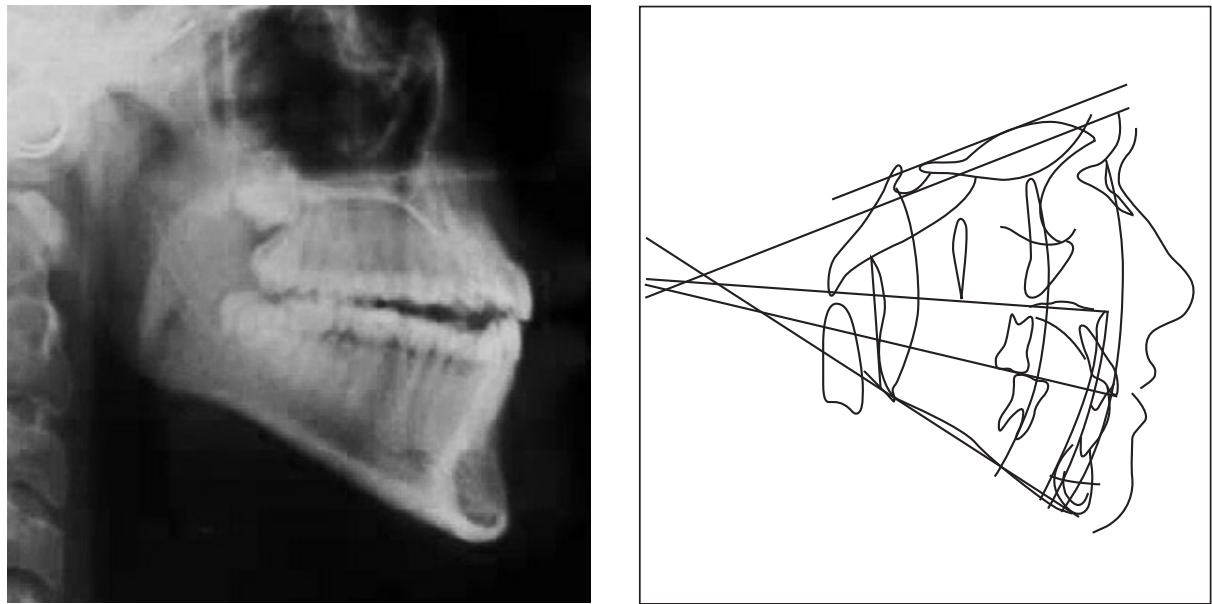

FIGURA 31 - Análise cefalométrica de Sassouni, indicando uma Classe III devido à retrusão maxilar e ligeira protrusão mandibular. A radiografia de punho indica maturidade óssea.
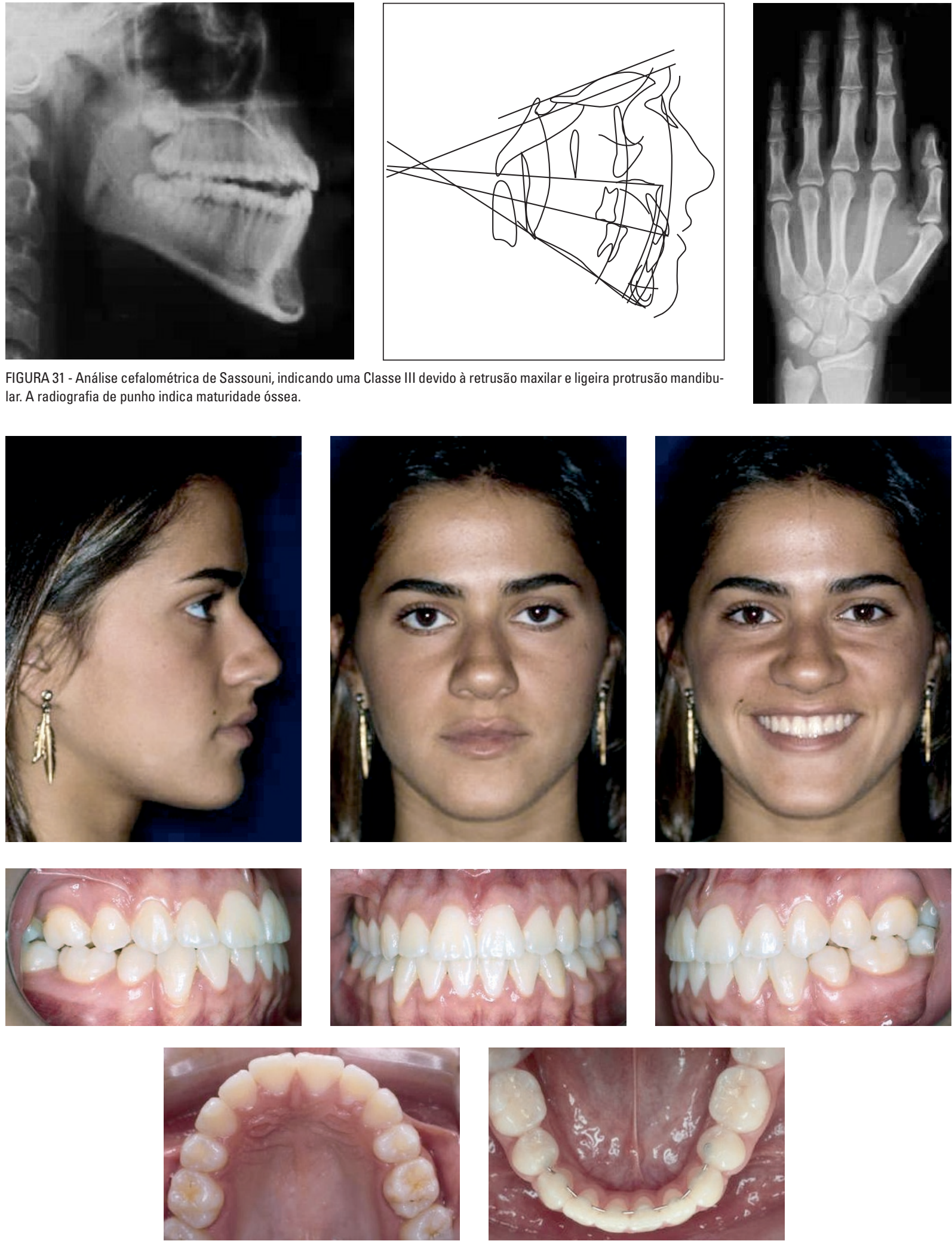

FIGURA 32 - Fotografias extrabucais e intrabucais após tratamento com extrações de pré-molares (segundos superiores e primeiros inferiores), aos 17 anos de idade. 

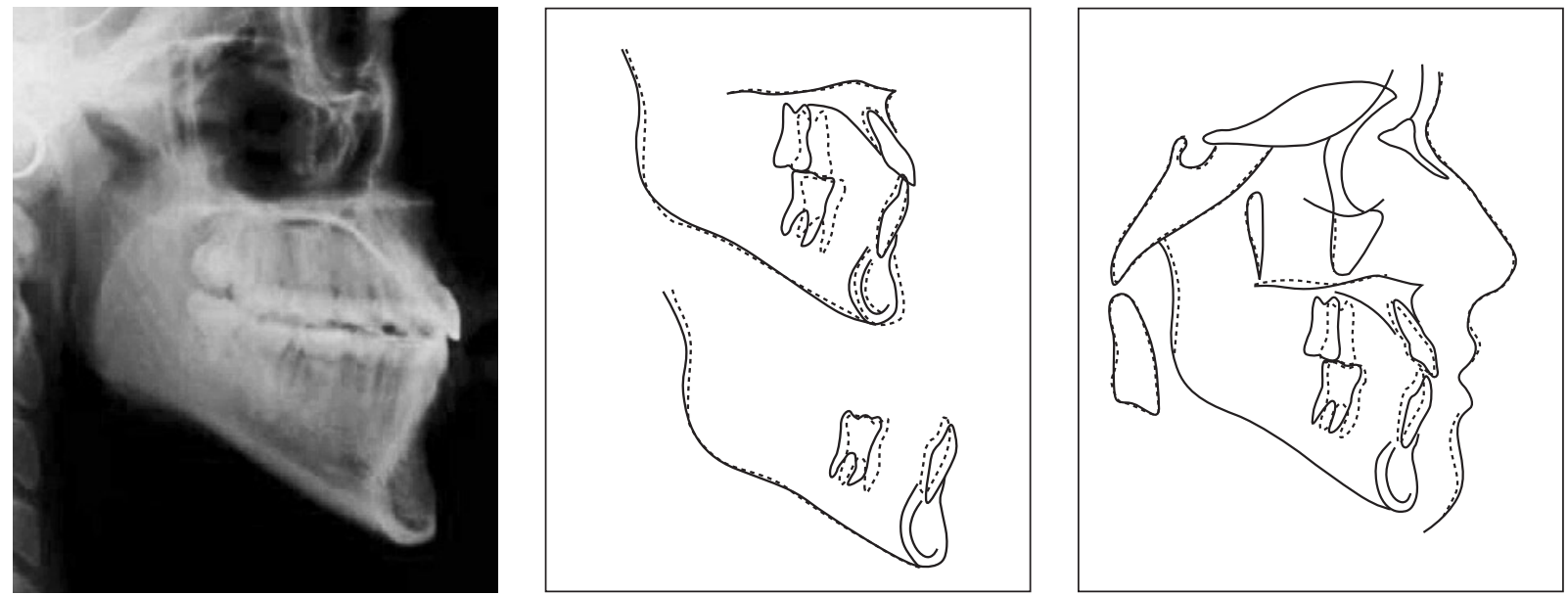

FIGURA 33 - Paciente aos 17 anos de idade, após tratamento com extrações de pré-molares (segundos superiores e primeiros inferiores). A sobreposição indica que não houve crescimento.
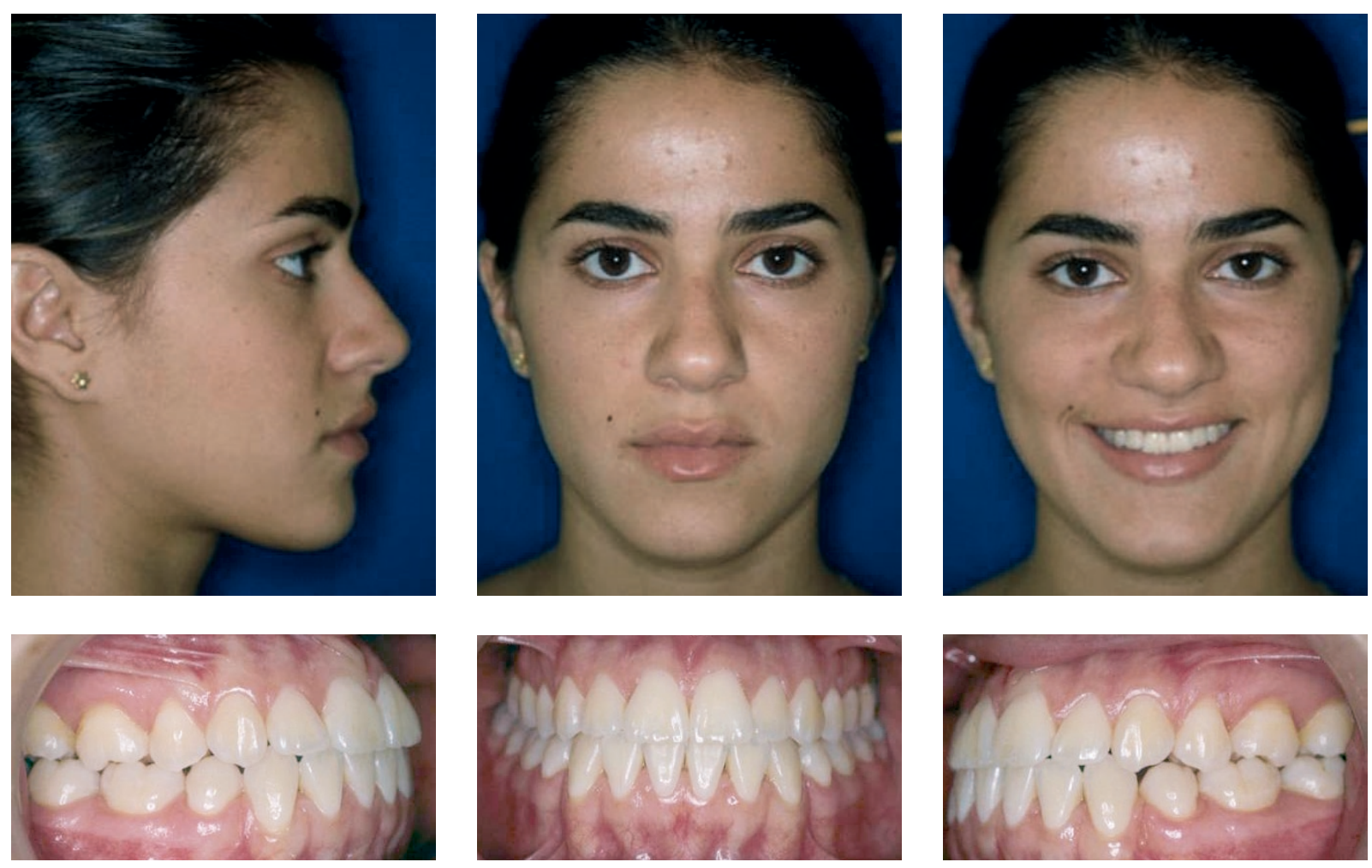

FIGURA 34 - Fotografias extrabucais e intrabucais 3 anos pós-tratamento com extrações de pré-molares (segundos superiores e primeiros inferiores). 
Tratamento com extração dos primeiros molares inferiores

Não raro, uma conduta clínica com a proposta de extração dos molares inferiores é vista com restrições no meio ortodôntico, mas sua indicação, se criteriosa, pode produzir bons resultados.

Dentre as vantagens de se optar por essa
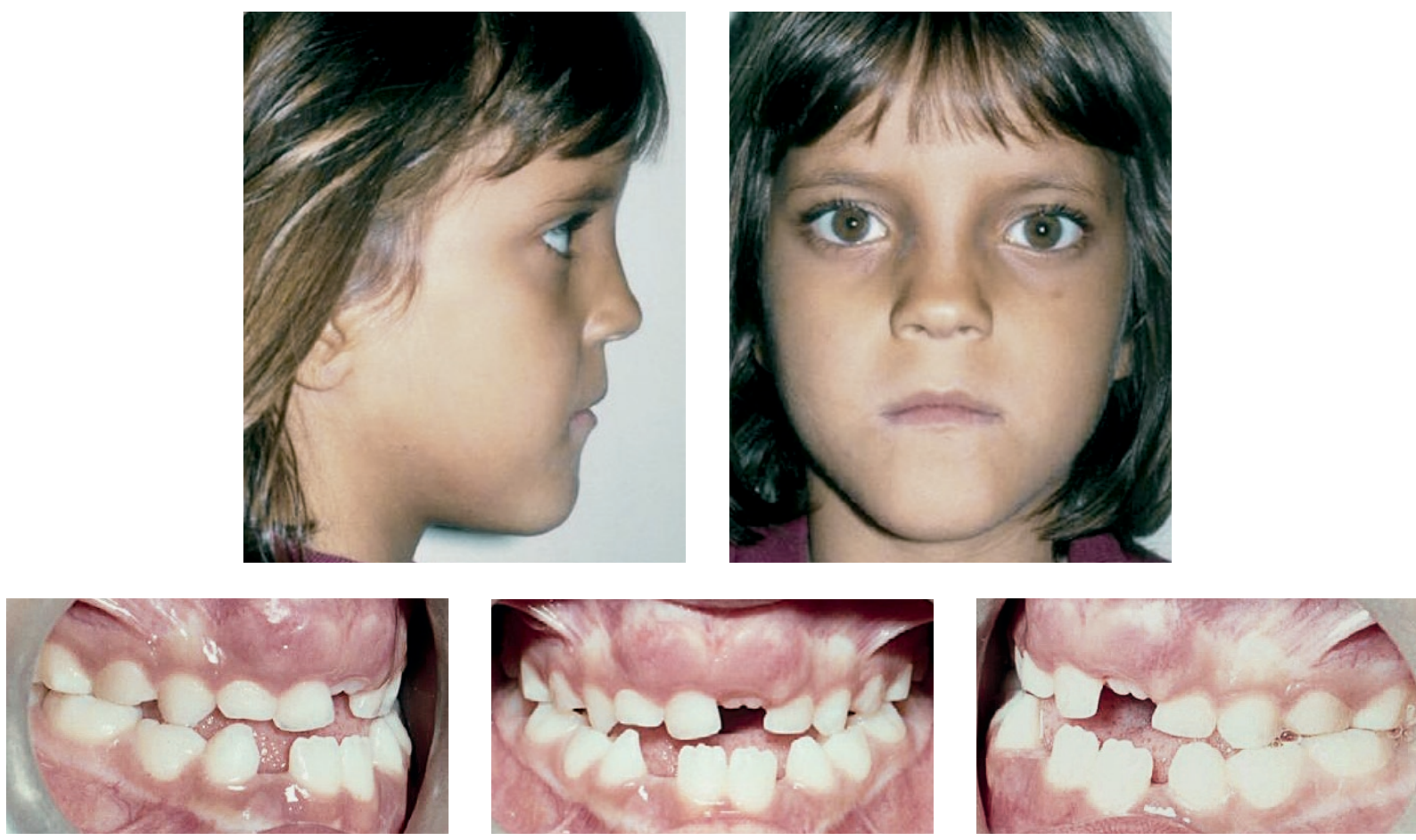

FIGURA 35 - Fotografias extrabucais e intrabucais pré-tratamento, aos 6,7 anos de idade.
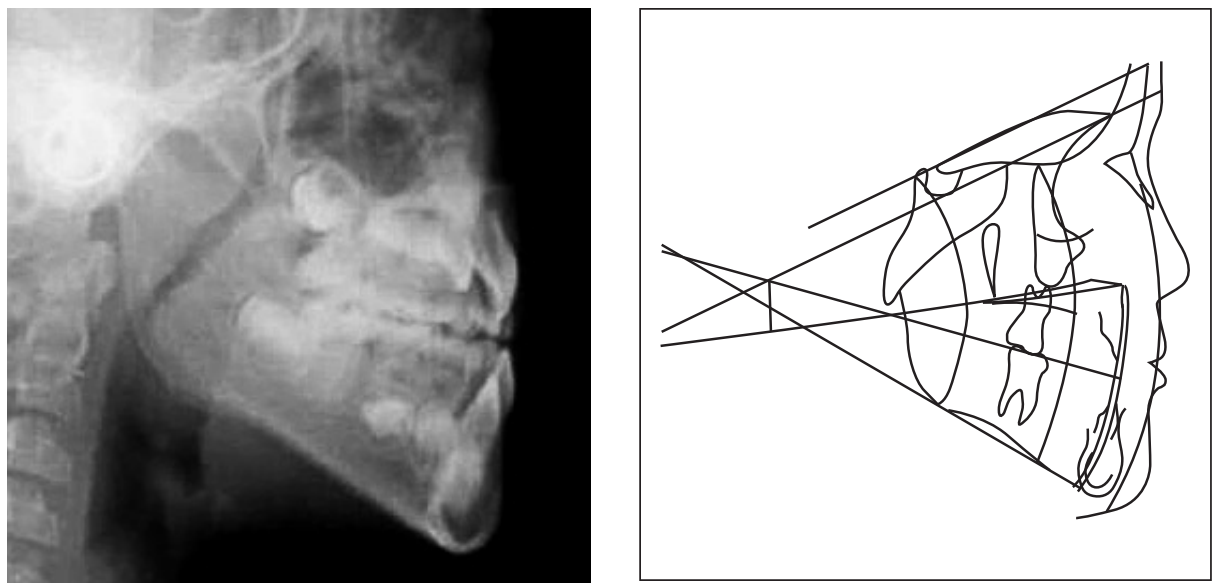

FIGURA 36 - Telerradiografia lateral e traçado cefalométrico pré-tratamento, aos 6,7 anos de idade, indicando uma retrusão maxilar e vertical ligeiramente aumentada. 
cimento moderado e, por fim, a correção através de cirurgia ortognática, em casos de crescimento exacerbado.

Entre as desvantagens, aponta-se a mecânica ortodôntica mais complicada e dependente de recursos cuidadosamente controlados, a duração prolongada do tratamento e a aparente agressividade da conduta. Pacientes com maior índice de apinhamento inferior e terceiros molares presentes são os melhores candidatos ao procedimento.
Os casos apresentados anteriormente nas figuras de 3 a 9, 17 e 18 ilustram a adequação da escolha da conduta. Os pacientes em questão apresentam face harmoniosa e agradável e uma relação oclusal normal, apesar das características ainda evidentes de Classe III.

As figuras 35 a 39 ilustram outro caso de remoção de molares inferiores. A paciente aos 6,7 anos de idade se apresentou para tratamento, época em que foi submetida a uma expansão palatina.
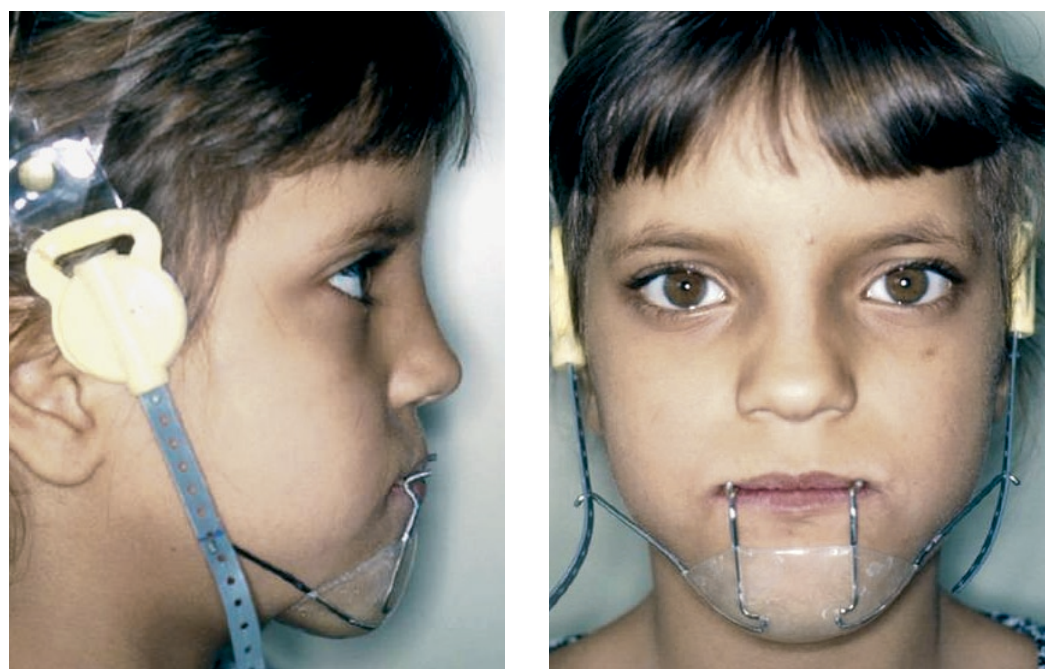

FIGURA 37 - Fotografias extrabucais de perfil e frontal aos 11 anos de idade, época de início do tratamento, com mentoneira de Hickham para protração ortopédica da maxila.
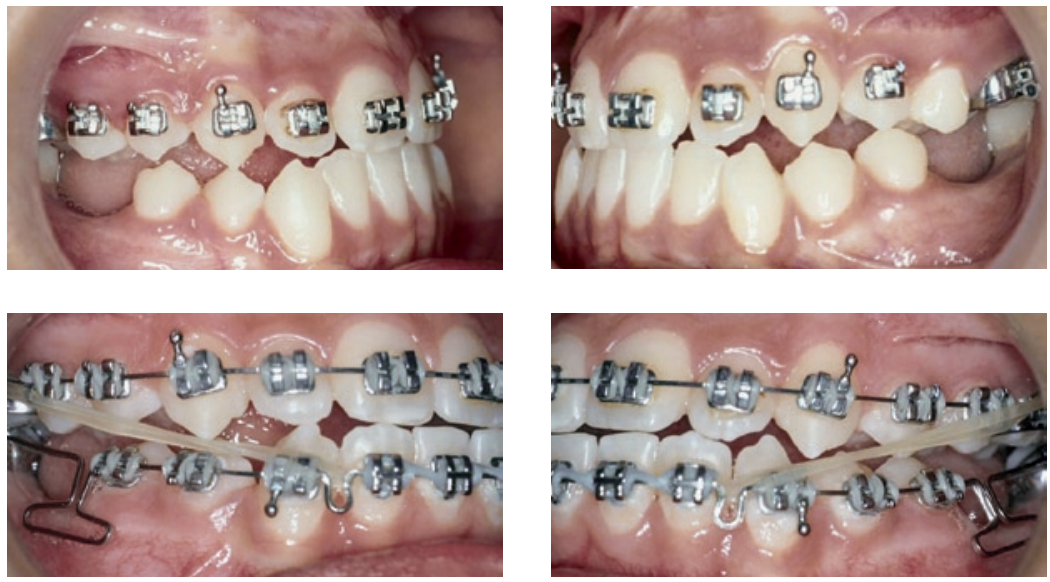

FIGURA 38 - Fotografias intrabucais após extração dos primeiros molares inferiores e durante mecânica de fechamento dos espaços. 

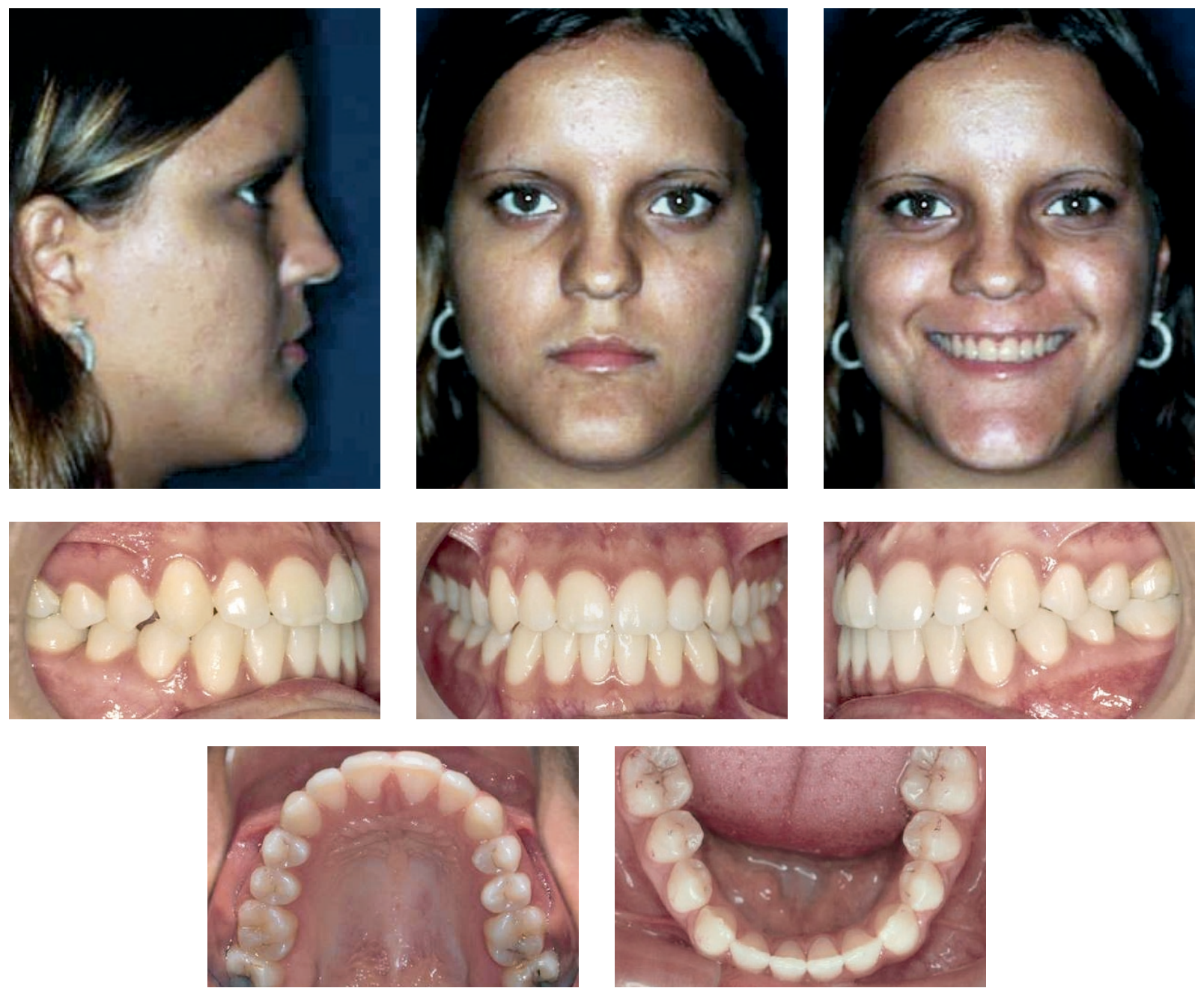

FIGURA 39 - Fotografias extrabucais e intrabucais finais, aos 15 anos de idade.

Quatro anos mais tarde, reiniciou o tratamento com protração maxilar, aparelho fixo total e extrações dos primeiros molares inferiores.

Todos os procedimentos de extração aqui descritos tendem a uma simplificação, uma vez que hoje existem dispositivos para ancoragem esquelética temporária.

\section{Finalização}

O processo de finalização de um tratamento não-cirúrgico de Classe III requer a observância dos seguintes pontos:

a) mecânica de elásticos com seleção de vetores que favoreçam a correção;

b) supercorreção com a manutenção de uma pequena sobressaliência;

c) intercuspidação dos segmentos posteriores através de elásticos verticais (acredita-se que os planos inclinados dentários sejam capazes de proporcionar ótima contenção);

d) distribuição correta de espaços superiores em caso de recomposição estética com resinas. 


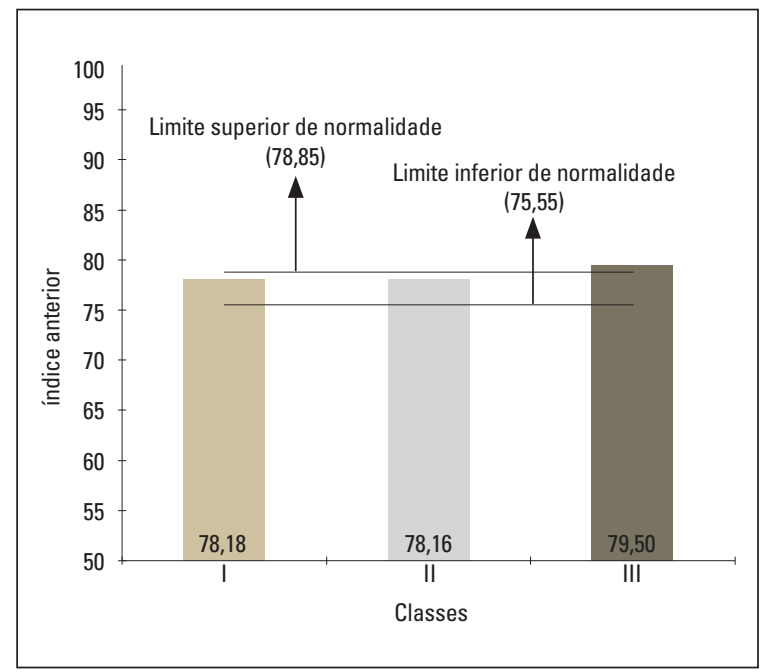

GRÁFICO 2 - Índices de discrepância de Bolton para as Classes I, II e III. (Fonte: ARAÚJO, SOUKI5).

Diversos relatos na literatura demonstram a presença de uma discrepância de Bolton nos portadores de Classe III ${ }^{5,31,38}$. O gráfico 2 mostra o resultado de um desses trabalhos.

\section{Contenção}

O período de contenção deve ser visto com a mesma importância que o período de tratamento ativo. Em pacientes ainda com potencial de crescimento, sugere-se adotar uma conduta mais conservadora com a utilização de uma mentoneira soft, o que pode evitar uma recidiva acentuada ${ }^{24}$.

Recomenda-se também uma placa Hawley de arco contínuo (wraparound), em cujo desenho não se encontra qualquer fio interferindo na oclusão. A melhor contenção, no entanto, talvez seja uma ótima finalização. No arco inferior, em casos sem exodontias ou com exodontia de um incisivo ou de primeiros molares, deve-se fazer uso de contenção fixa de canino a canino. Nos casos de extração de primeiros pré-molares, a contenção fixa estende-se até os segundos pré-molares.

\section{Avaliação do tratamento e reavaliação de crescimento}

A ultima etapa deste protocolo engloba a avalia- ção do tratamento e, ao final do crescimento, uma reavaliação. A avaliação deve ser feita com critérios especiais para análise do comportamento da mandíbula e da maxila. Sugere-se a aplicação de métodos de sobreposição de traçados cefalométricos que possam mostrar com mais precisão o caminho percorrido pelas estruturas dentofaciais durante todo o processo de camuflagem da Classe $\mathrm{III}^{7}$.

A reavaliação do crescimento determinará a necessidade ou não de uma nova conduta ortodôntica. Em face de um resultado estável, descarta-se um novo tratamento. Caso contrário, pode-se recorrer a um retratamento sem extrações, com ou sem desgastes interproximais, um retratamento com nova conduta de extrações ou, em casos extremos, uma intervenção orto-cirúrgica.

\section{CONCLUSÃO}

Apesar da experiência de inúmeros resultados bem sucedidos, permanecem sem resposta definitiva muitos dos questionamentos a respeito do tema abordado. Advoga-se, mesmo assim, o início de terapias interceptativas em pacientes mais jovens.

Nos casos de Classe III, uma verdade é cristalina: o crescimento, grande aliado da Ortodontia em outras correções, torna-se um adversário - quanto mais intenso e duradouro mais severo o problema.

Este trabalho é um convite a pesquisas e debates que, certamente, enriquecerão o conhecimento sobre esta matéria tão desafiadora e estimulante.

\section{AGRADECIMENTOS}

Agradecemos a Terezinha Araújo, esposa e mãe, por sua inestimável cooperação neste traba1ho. Agradecemos também ao residente de Ortodontia da Saint Louis University, David Cameron, por sua valiosa ajuda. 


\title{
Non-surgical approaches to Class III malocclusions treatment
}

\begin{abstract}
Orthodontic management of the Class III malocclusion has been a constant challenge to the orthodontic profession and remains a controversial issue among clinicians and researches. Some support the belief that growth and size of the craniofacial complex are genetically predetermined and cannot be changed. They assume that the great majority of Class III cases are "untreatable" and that they are due to surgical intervention after growth has been completed. Even agreeing that heredity plays a major role in this type os deviation, others support the contention that the pattern and direction of growth can be modified and that forces generated in orthodontic treatment are able to minimize and even successfully correct some Class III. The controversy is real and one question is still to be answered: How much can orthodontics really do? The literature provides enough support that appropriate interventions at the adequate time, accompanied by a family growth study may very well minimize or camouflage the Class III to acceptable and stable results without a surgical intervention. There are clinical and scientific evidences that selected procedures can change questionable prognosis.
\end{abstract}

Key words: Class III treatment. Malocclusion. Class III camouflage.

\section{REFERÊNCIAS}

1. AMARAL, R. L. Avaliação cefalométrica através de um Wigglegram: uma nova proposta. 1998. Trabalho de Conclusão de Curso (Especialização)-Faculdade de Odontologia, Pontifícia Universidade Católica de Minas Gerais, Belo Horizonte, 1998.

2. ANDREWS, L. F. The six keys to normal occlusion. Am. J. Orthod., St. Louis, v. 62, no. 3, p. 296-309, Sept. 1979.

3. ANGLE, E. H. Classification of malocclusion. Dental Cosmos, Philadelphia, v. 41, no. 18, p. 248-264, Mar. 1899.

4. ARAT, Z. M.; AKÇAM, M. O.; GÖKALP, H. Long-term effects of chincap therapy on the temporomandibular joints. Eur. J. Orthod., Oxford, v. 25, no. 5, p. 471-475, Oct. 2003.

5. ARAÚJO, E. A.; SOUKI, M. Bolton anterior tooth size discrepancies among different malocclusion groups. Angle Orthod., Appleton, v. 73, no. 3, p. 307-313, June 2003.

6. ARAÚJO, E. A. Hereditariedade em Ortodontia. In: SAKAI, E. et al. Nova visão em Ortodontia e Ortopedia Facial. São Paulo: Sociedade Paulista de Ortodontia, 2000.

7. ARAÚJO, E. A.; KIM, B. J.; WOLF, G. Two superimposition methods to assess Class III treatment. Semin. Orthod. Philadelphia, v. 13, no. 3, p. 200-208, Sept. 2007.

8. BACCETTI, T.; FRANCHI, L.; MCNAMARA JR., J. A. Growth in the untreated Class III subject. Semin. Orthod., Philadelphia, v. 13, p. 130-142, Sept. 2007.

9. BOARD BRASILEIRO DE ORTODONTIA E ORTOPEDIA FACIAL. Manual de normas para certificação. Disponível em: <http://www.bbo.org.br/> Acesso em: 4 jun. 2008

10. BOLTON, W. A. The clinical application of tooth-size analysis. Am. J. Orthod., St. Louis, v. 48, no. 7, p. 504-529, July 1962.

11. BRODIE, A. G. On the growth pattern of the human head: from the third month to the eight year of life. Am. J. Anat., Chicago, v. 68, no. 2, p. 209-262, Mar. 1941.

12. DEGUCHI, T.; UEMATSU, S.; KAWAHARA, Y.; MIMURA, H. Clinical evaluation of temporomandibular joint disorders (TMD) in patients treated with chincup. Angle Orthod., Appleton, v. 68 , no. 1, p. 91-94, Feb. 1998.

13. DEGUCHI, T.; McNAMARA, J. A. Craniofacial adaptations induced by chincup therapy in Class III patients. Am. J. Orthod. Dentofacial Orthop., St. Louis, v. 115, no. 2 , p. 175-182, Feb. 1999.
14. DEGUCHI, T.; KURODA, T.; HUNT, N. P.; GRABER, T. M. Longterm application of chincup force alters the morphology of the dolichofacial Class III mandible. Am. J. Orthod. Dentofacial Orthop. St. Louis, v. 116, no. 6, p. 610-615, Dec. 1999.

15. GRABER, L. W.; LUCKER, G. W. Dental esthetic self-evaluation and satisfaction. Am. J. Orthod., St. Louis, v. 77, no. 2, p. 163-173, Feb. 1980.

16. HARRIS, J. E.; KOWALSKI, J. All in the family: use of familial information in orthodontic diagnosis, case assessment and treatment planning. Am. J. Orthod., St. Louis, n. 69, no. 5 p. 493-510, May 1976.

17. HARRIS, J. E.; KOWALSKI, C. J.; WALKER, S. J. Intrafamilial dentofacial association for Class II, division1 probands. Am. J. Orthod., St. Louis, v. 67, no. 5, p. 563-570, May 1975.

18. HICKHAM, J. H. Maxillary protraction therapy: diagnosis and treatment. J. Clin. Orthod., Boulder, v. 25, no. 2, p. 102-113, Feb. 1991.

19. ISHII, H. Treatment effect of combined maxillary protraction and chincap appliance in severe skeletal Class III cases. Am. J. Orthod. Dentofacial Orthop., St. Louis, v. 92, no. 4 , p. 304-312, Oct. 1987

20. JANZEN, E. K.; BLUHER, J. A. The cephalometric anatomic and histologic changes in the Macaca mulatta after application of a continuous-acting retraction force on the mandible. Am. J. Orthod., St. Louis, v. 51, no. 11, p. 823-855, Nov. 1965.

21. KREBS, A. Midpalatal suture expansion studies by the implant method over a seven-year period. Rep. Congr. Eur. Orthod. Soc., [s.l.], v. 40, p. 131-142, 1964.

22. KROGMAN, W. M. Child growth. Ann Arbor: University of Michigan Press, 1972.

23. MIMURA, H.; DEGUCHI, T. Morphologic adaptation of temporomandibular joint after chincup therapy. Am. J. Orthod. Dentofacial Orthop., St. Louis, v. 110, no. 5, p. 541-546, Nov. 1996.

24. MITANI, H. Recovery growth of the mandible after chin cup therapy: fact or fiction. Semin. Orthod., Philadelphia, v. 13, p.186-199, Set. 2007.

25. MONSON, J. W.; FELTS, W. J. Transplantation studies of factors in skeletal organogenesis. Am. J. Phys. Anthropol. New York, v. 19, p. 63-77, Mar. 1961. 
26. MOREIRA, R. C.:ARAÚJO, E. A. Freqüência das exodontias em tratamentos ortodônticos realizados na clínica do Curso de Especialização em Ortodontia do Centro de Odontologia e Pesquisa da Pontifícia Universidade Católica de Minas Gerais. Rev. Bras. Ortod. Ortop. Dentofacial, Belo Horizonte, v. 3 n. 2, p. 49-53, 2000.

27. MOSSEY, P. A. The heritability of malocclusion - Part 2: the influence of genetics in malocclusion. Br. J. Orthod., Oxford, v. 26, no. 3, p. 195-203, July 1999.

28. MUKAIYAMA, T.; FUKAZAWA, H.; MIZOGUCHI, I.; MITANI, $H$. Prevalence of temporomandibular joint dysfunction for 6-10-year old Japanese children with chincap orthodontic treatment. Nippon Kyosei Shika Gakkai Zasshi, Tokyo, v. 47, no. 2, p. 425-432, June 1988.

29. MYRBERG, N.; THILANDER, B. An evaluation of the duration and the results of orthodontic treatment. Scand. J. Dent. Res., Oslo, v. 81, no. 2, p. 85-91, Feb. 1973.

30. NGAN, P. Biomechanics of maxillary expansion and protraction in Class III patients. Am. J. Orthod. Dentofacial Orthop., St. Louis, v. 121, no. 6, p. 582-583, June 2002.

31. NIE, Q.; LIN, J. Comparison of intermaxillary tooth size discrepancy among different malocclusion groups. Am. J. Orthod. Dentofacial Orthop., St. Louis, v. 116, no. 5, p. 539544, Nov. 1999

32. PÉRES-MARTINEZ, C. Cranio deformations among the guanes indians of Colombia. Am. J. Orthod., St. Louis, v. 46, p. 439543 , July 1960.
33. RAKOSI, T. SCHILLI, W. Class III anomalies: a coordinated approach to skeletal, dental, and soft tissue problems. J. Oral Surg., Orlando, v. 39, no. 11, p. 860-870, Nov. 1981.

34. REYNDERS, R. M. Orthodontics and temporomandibular disorders: a review of the literature (1966-1988). Am. J. Orthod. Dentofacial Orthop., St. Louis, v. 97, no. 6, p. 463471, June 1990.

35. SALZMANN, J. A. Genetic consideration in clinical Orthodontics. Am. J. Orthod., St. Louis, v. 4, no. 74, p. 467468, Oct. 1978.

36. SASSOUNI, V. Dentofacial Orthopedics. Pittsbugh: C. О. T. Publications, 1971

37. SASSOUNI, V. Orthopedics in dental practice. St. Louis: C. V. Mosby, 1971.

38. SPERRY, T. P. et al. Tooth-size discrepancy in mandibular prognatism. Am. J. Orthod., St. Louis, v. 72, no. 2, p. 183-190, Aug. 1977.

39. TURLEY, P. K. Orthopedic correction of Class III malocclusion with palatal expansion and custom protraction headgear. J. Clin. Orthod., Boulder, v. 22, no. 5, p. 314-325, May 1988

40. VAN DER WEELE, L. T.; DIBBETS, J. M. Conceptual models for analyzing symptoms of temporomandibular joint dysfunction. Cranio, Chatanooga, v. 4, no. 4, p. 357-366, Oct. 1986.
Endereço para correspondência

Eustáquio A. Araújo

St. Louis, MO - 63104

E-mail: araujoea@slu.edu 